\title{
Kinematic and Petroleum Modeling of the Alberta Foothills and Adjacent Foreland - West of Calgary
}

\author{
J.L. Faure' ${ }^{1}$, K. Osadetz ${ }^{2}$, Z.N. Benaouali' ${ }^{1}$, F. Schneider' and F. Roure ${ }^{1}$ \\ 1 Institut français du pétrole, 1 et 4, avenue de Bois-Préau, 92852 Rueil-Malmaison Cedex - France \\ 2 Geological Survey of Canada, 3303 - 33rd Street NW, Calgary, Alberta - Canada \\ e-mail: j-luc.faure@ifp.fr
}

\begin{abstract}
Résumé - Cinématique et modélisation pétrolière des zones externes des montagnes Rocheuses de l'Alberta à l'ouest de Calgary - Cet article résume les principaux résultats d'une étude intégrée utilisant les données pétrolières de surface et de subsurface, réalisée avec les outils de modélisation pétrolière récemment développés à l'IFP, le long d'un transect recoupant le front des Rocheuses canadiennes de l'Alberta, entre Banff et Calgary.

Dans toutes chaînes de montagnes, les compressions sont à l'origine d'un important raccourcissement tectonique, mais aussi d'importants mouvements verticaux impliquant de fortes érosions. Dans un premier temps, nous avons calculé les profils d'érosion, à partir de puits réels ou fictifs, grâce à une modélisation thermique avec le logiciel 1D Genex-Gentec. Ces profils ont permis de reconstruire la géométrie antécompression du bassin flexural crétacé de l'Alberta. Dans un deuxième temps, une modélisation cinématique et thermique directe du front des Rocheuses a été entreprise avec le logiciel 2D Thrustpack. Elle a fourni :

- les géométries du bassin depuis les stades préorogéniques jusqu'au stade actuel, en passant par le stade $\mathrm{du}$ «bassin flexural » et les différentes étapes de plissement et de chevauchement;

- les fenêtres de maturité des différentes roches mères paléozoïques et mésozoïques en considérant un transfert thermique purement conductif.

Ces géométries ont ensuite été utilisées comme conditions aux limites du logiciel Ceres pour modéliser les mouvements et les pressions de fluides, ainsi que la migration des hydrocarbures et leur piégeage dans les anticlinaux.

Les résultats de cette étude améliorent considérablement notre compréhension de la chronologie de la genèse et du piégeage des hydrocarbures dans les réservoirs gréseux du Crétacé, et surtout, dans les réservoirs carbonatés du Dévonien-Carbonifère, à partir des roches mères du Crétacé et du DévonienCarbonifère.
\end{abstract}

Abstract-Kinematic and Petroleum Modeling of the Alberta Foothills and Adjacent Forelant - West
of Calgary - This paper summarizes the main results of an integrated study using surface and
subsurface geological data and IFP's basin modeling tools along a regional transect crossing the Alberta
foothills and adjacent foreland between Banff and Calgary.
Cretaceous subsidence history in the foreland and subsequent erosional profiles in both the autochthon
and the allochthon were computed using $1 D$ Genex-Gentec modeling on both real and fictive wells, 
calibrated by means of maturity ranks of the organic matter. Subsequently, 2D forward kinematic and thermal Thrustpack modeling was used to reconstruct:

- intermediate geometries of the foothills from its initial, preorogenic architecture (Mid-Cretaceous), until Present, taking into account incremental Late Cretaceous-Paleocene deformation and thrusting, as well as subsequent uplift and erosion;

- and maturity windows of potential Paleozoic and Mesozoic source rocks assuming purely conductive heat transfers.

Geometric results of the Thrustpack forward modeling were ultimately used as intermediate boundary conditions for a regional $2 D$ fluid flow modeling using the Ceres software. Ceres was also used to derive instant pore fluid pressures in potential reservoirs, and to compute the hydrocarbon migration and charge of frontal anticline and buried duplex structures.

Results of the study help to better understand the timing of two petroleum systems accounting for the oil and gas charge of Cretaceous sandstone reservoirs and Devonian-Mississippian carbonate reservoirs from foothills prospects, from either Mesozoic, dominantly Cretaceous, or Devonian-Mississippian source rocks, respectively.

\section{INTRODUCTION}

In the scope of the Subtrap (Subthrust Reservoir Appraisal) Consortium, IFP initiated in 1996 a collaboration with a number of national and international oil companies, universities and research institutes to unravel the thermal, diagenetic and deformation evolution of subthrust carbonate and sandstone reservoirs in various foreland fold and thrust belts around the world (Roure et al., 2000; Roure and Swennen, 2002). For each of these Subtrap regional transects, surface and subsurface geological data were used to constrain the structural sections, and to calibrate basin modeling simulations, aiming at reconstructing the burial and temperature evolution of both reservoir and source rocks horizons, thus providing key constraints on the P-T conditions of the diagenesis, but also direct information on the history of the regional petroleum systems.

This paper, based on a Canadian case study performed in 2000-2001 in collaboration with the Geological Survey of Canada in the scope of the Subtrap project, will focus on the integrated methodology used for the study of petroleum systems in tectonically complex areas. We shall describe here the main structural results and petroleum history of the Alberta foothills and adjacent foreland (Faure et al., 2002a, 2002b; Benaouali et al., 2003; Schneider, 2003). Additional results obtained in collaboration with the universities of Leuven (Swennen et al., 2002a; Swennen et al., 2002b) and Cergy (Robion et al., 2004) on the deformation and reservoir characteristics of Upper Paleozoic carbonate formations will be presented elsewhere.

\section{REGIONAL GEOLOGICAL AND PETROLEUM BACKGROUND}

The Canadian Rocky Mountain foreland thrust and fold belt (Gabrielse and Yorath, 1992) is a northeastward tapering deformational belt. It consists of Mesoproterozoic, Paleozoic and Mesozoic strata from several different depositional basins that have been scraped off the under-riding North American craton and accreted to the over-riding Intermontane terrane during Late Jurassic to Paleocene convergence between them (Monger and Price, 1979; Price, 1981; McMechan and Thompson, 1989; Price, 1994). The geological structure within the deformational belt is dominated by thrust faults, most of which are listric and northeasterly or easterly verging. The thrust faults commonly follow long bedding parallel detachments that are separated by ramps along which the faults change stratigraphic level abruptly (Figs. 1 and 2; Douglas, 1950; Bally et al., 1966; Dahlstrom, 1970; Fermor, 1999). The thrusts merge downward with a basal detachment that converges with the contact between the sedimentary rocks and the underlying crystalline basement. The westward dipping basal detachment extends into the Cordilleran metamorphic core at mid-crustal levels (e.g. Price and Fermor, 1985). The thrust faults generally cut up through the stratigraphic succession in the direction of displacement of the hanging wall and they generally juxtapose older strata over younger, causing stratigraphic repetitions. The supracrustal cover has been vertically thickened and horizontally shortened.

The total horizontal shortening across the foreland thrust and fold belt is localized mainly on a small number of major thrust faults with large displacement. One of the largest of these is the McConnell thrust, which forms the bounding fault of the Front range within this model (Fig. 3). Fault bend and detachment folding occurred in conjunction with the thrusting and fold related strain varies along strike with stratigraphically controlled changes in mechanical properties of the stratigraphic succession. In the southern foreland belt, folds make a relatively small contribution to the overall horizontal shortening, however, many thrust faults are folded with underlying strata as a result of fault bend and detachment folding. Thrusting and folding within the 


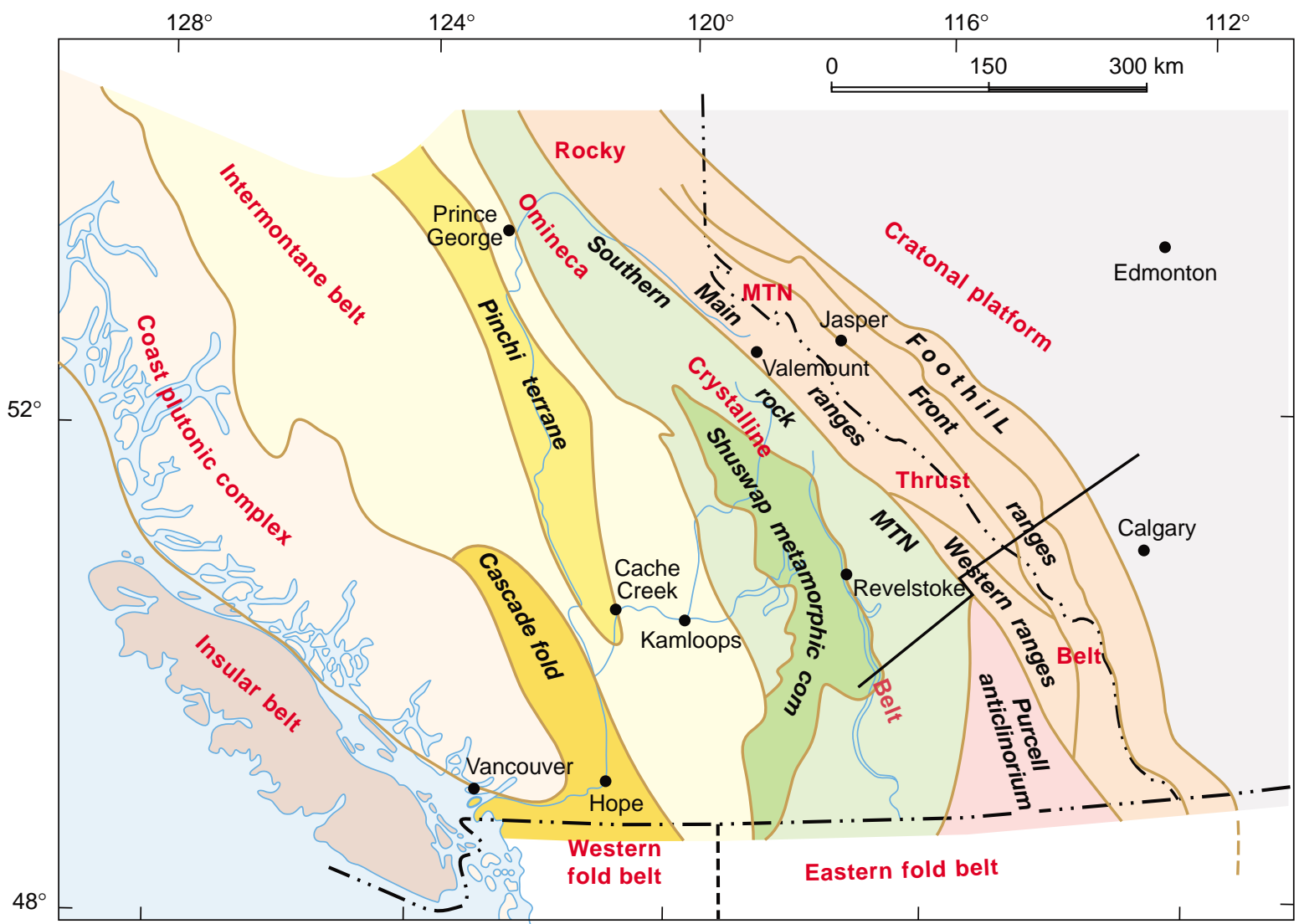

Figure 1

Synthetic map outlining the main structural subdivision of the North American Cordillera in southwestern Canada, and the location of the studied transect.

northeastward tapering wedge of supracrustal rocks along the western flank of the North American craton increased its thickness by $>10 \mathrm{~km}$. The resulting tectonic load produced a lithospheric flexure in which up to $8 \mathrm{~km}$ of Upper Jurassic, Cretaceous and Paleocene foreland basin sediments accumulated concurrently with the deformation (Price, 1973; Beaumont, 1981; Mack and Jerzykiewicz, 1989; Peper, 1993). Foreland basin deposits were incrementally incorporated into the thrust and fold belt as it expanded toward the craton.

Late Cretaceous and Paleocene thrusting in the southern Canadian Rocky Mountains foothills and eastern Front ranges was associated with oblique, right-hand convergence between the Intermontane terrane and the North American craton (Price, 1994). In the south-central Canadian Cordillera, the oblique right-hand transpression was replaced by Late Paleocene to Middle Eocene right-hand transtension (Ewing, 1980; Price, 1994) involving conspicuous east-west crustal extension and the tectonic exhumation of mid-crustal metamorphic rocks, including Archean and Paleoproterozoic basement rocks (Carr et al., 1987; Parrish et al., 1988; Doughty and Price, 1999, 2000). This change from regional horizontal compression to regional horizontal extension has been inferred to mark the end of both thrusting and folding in the foreland belt, and the flexural subsidence of the foreland basin (Price, 1994).

Late Paleocene-Middle Eocene and younger crustal extension and the uplift of mid-crustal metamorphic core complexes in the Omenica belt (Carr, 1992; Lorencak et al., 2001; Doughty and Price, 1999, 2002; Vanderheghe et al., 2003) was accompanied by westward increasing erosional exhumation of the Foreland thrust and fold belt and the adjacent margin of the undeformed Interior platform. The thickness of strata eroded increases westward from about $2-3 \mathrm{~km}$ at the eastern edge of the fold and thrust belt (Magara, 1976; Hacquebard, 1977; Nurkowski, 1984; England and Bustin, 1986a; Issler et al., 1990; Majorowicz et al., 1990), to $>8 \mathrm{~km}$ in the southern portions of the Front range (Osadetz et al., 2003). Farther west, in the metamorphic core complexes of the Omineca crystalline belt (Fig. 1), isostatic uplift of mid-crustal rocks is commonly $>25 \mathrm{~km}$, and the basal detachment of the Cordilleran foreland thrust and fold is exposed locally at $>2 \mathrm{~km}$ above sea level (Parrish et al., 1988; Carr, 1992). 

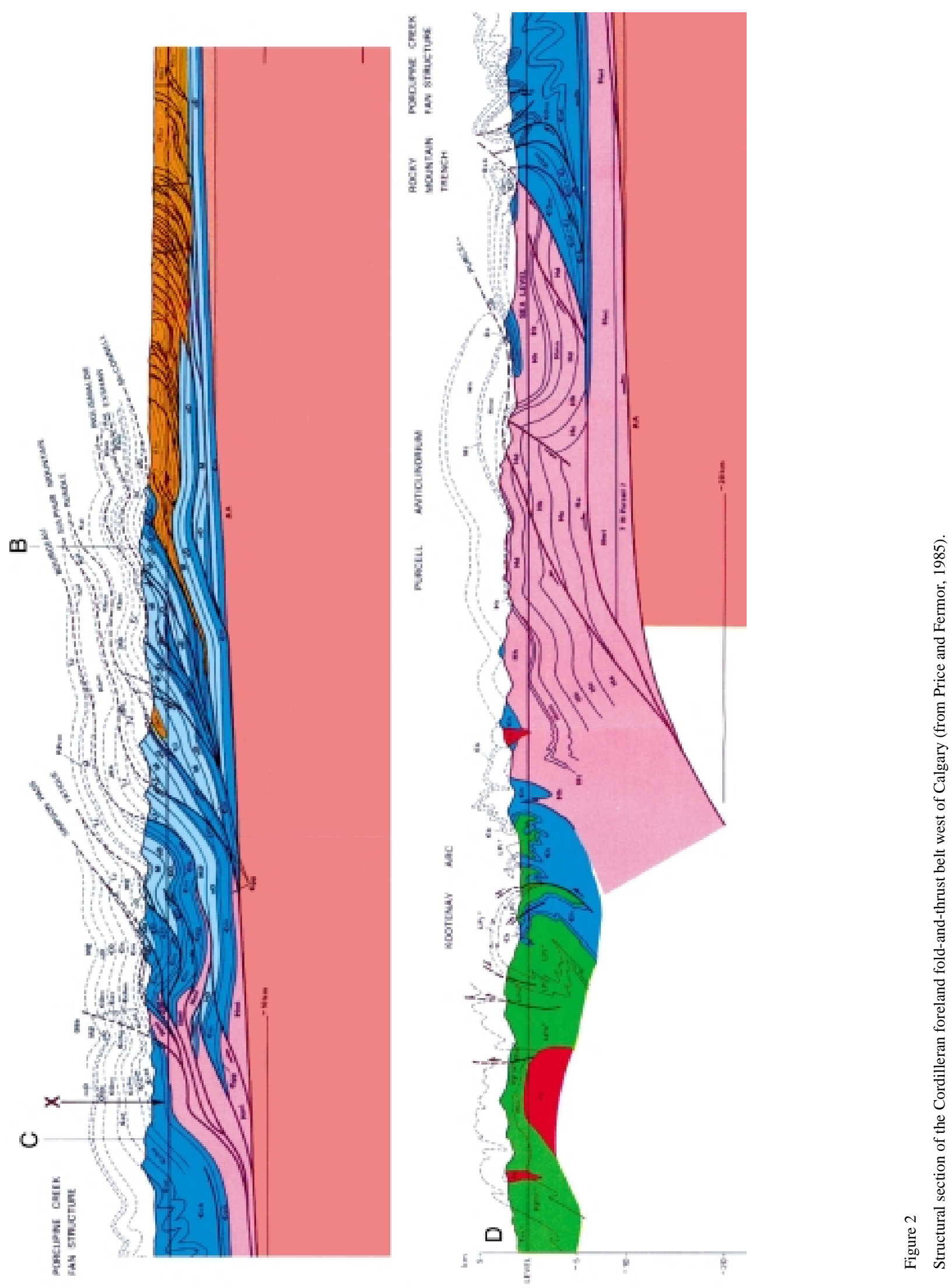


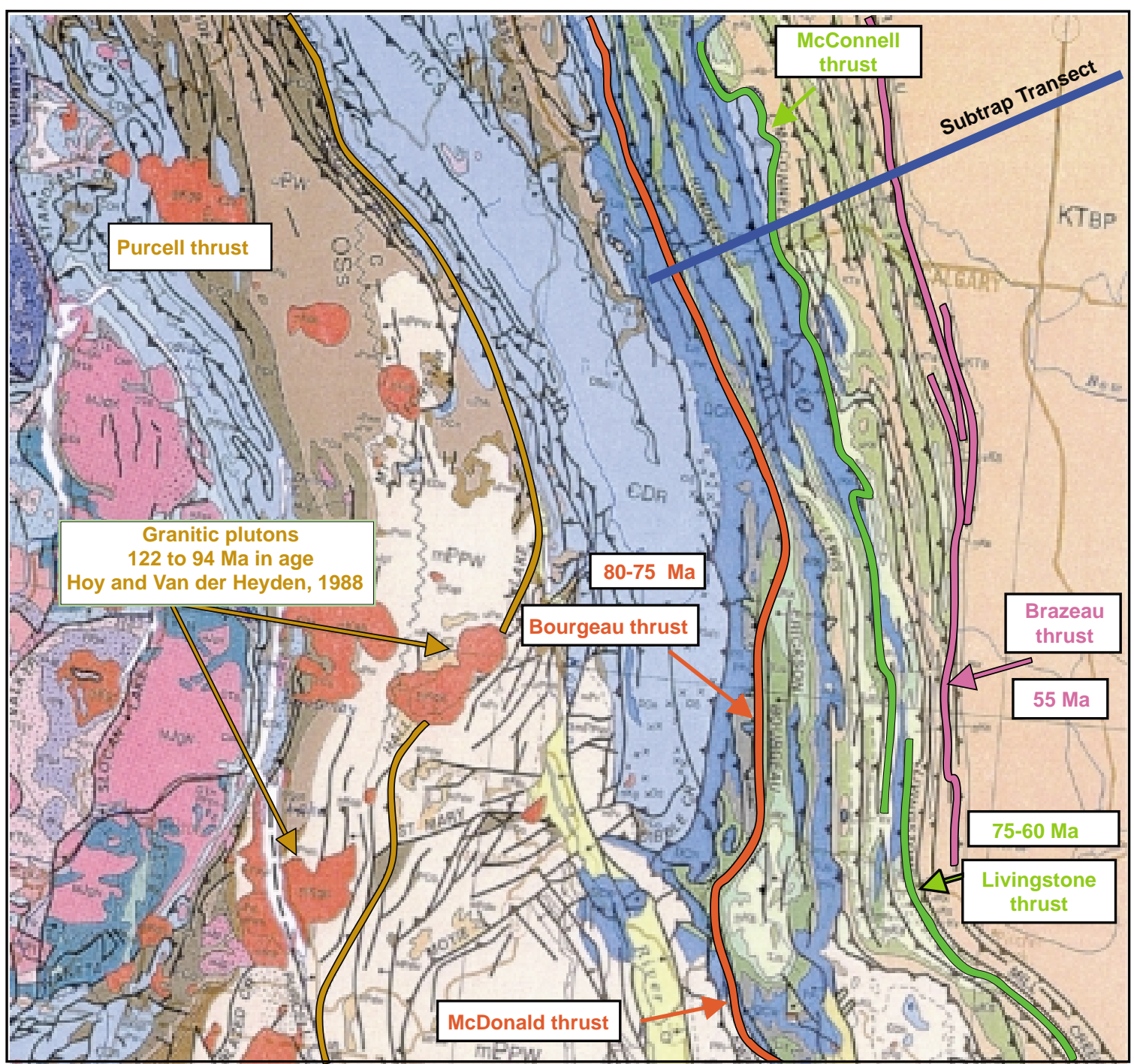

Figure 3

Regional map outlining the location of the Canadian Subtrap transect with respect to the main thrust fronts. Tentative agenda of individual thrust emplacement is also indicated.

Upper Cretaceous strata occur in the footwall of the McConnell thrust along most of the eastern edge of the thrust sheet in southwestern Alberta (Price, 1994). To the south in Alberta and Montana the McConnell thrust transfers displacement to the Lewis thrust, which has similar footwall stratigraphic relationships (Price, 1962; Mudge and Earhart; 1980). Thus, along much of the Front range the McConnell and Lewis thrusts evidently follows a major footwall detachment zone within Campanian-Maastrichtian strata (Fermor and Price, 1987; Fermor and Moffat, 1992; Jerzykiewicz et al., 1996). East of the Front range individual thrust sheets and duplex structures, like Moose Mountain, contain large petroleum accumulations (Fermor and Moffat, 1992).

These relationships mean that the thermal history described by the model is directly relevant to the analysis of foreland petroleum occurrences. Petroleum resource variations along the Canadian Cordilleran foreland belt (Stockmal et al., 2001; Fig. 1) show the important influence of thermo-tectonic history on petroleum resource potential. In this study we examine the southern Canadian Cordillera to evaluate the tectonic evolution of a prolific petroleum province, in which more than 900 billion cubic metters of initial in place raw gas have been discovered in $>680$ pools (ibid.). Our study was performed in the vicinity of Jumping Pound and Moose Mountain petroleum fields, large accumulations in the southern Canadian foreland belt. Extensive and continuing petroleum exploration in this region has provided a constrained model of the structure and tectonic evolution (Bally et al., 1966; Fermor and Moffat, 1992). 


\subsection{Location of the Cross-Section and Overall Structural Style}

The cross-section studied here is situated in Alberta, between Calgary and Banff, and is approximately parallel to the Trans-Canada Highway (Figs. 1, 2 and 3). This transect has been studied by a number of Canadian colleagues, the section used in our project being already compiled from surface outcrops and subsurface data (wells, seismic profiles), and was already accurately balanced by Price and Fermor (1985). Rocky Mountains belt and adjacent Canadian foreland can be divided into four different parts. From east to west, they comprise:

- The Interior plains (foreland autochthon), where the stratigraphy remains undisturbed by the Laramide Orogeny. Here, the youngest outcrops typically comprise the lower part of the Paleocene or younger continental sediments of Oligocene or Plio-Quaternary age.
- In the foothills, the main outcrops belong to the innermost part of the Upper Cretaceous clastic sedimentary infill of the former foreland flexural basin, which has been subsequently accreted into the tectonic wedge. These strata are cut by numerous, steeply dipping imbricated thrust faults, which merge downward with regional detachments located within the Jurassic-Cretaceous Fernie and Kootenay formations and, ultimately, to a basal decollement located near the base of Cambrian formations. This implies that the Precambrian crystalline basement is not involved in the foreland nor in the foothills deformation, whereas Paleozoic carbonate formations of the former passive margin constitute locally deeply buried antiformal stacks in the westernmost part of this domain, which have been proved productive in the Moose Mountain anticlinorium (Fig. 4).

- The Front ranges comprise several linear mountain ranges, each formed by steeply west-dipping homoclinal thrust

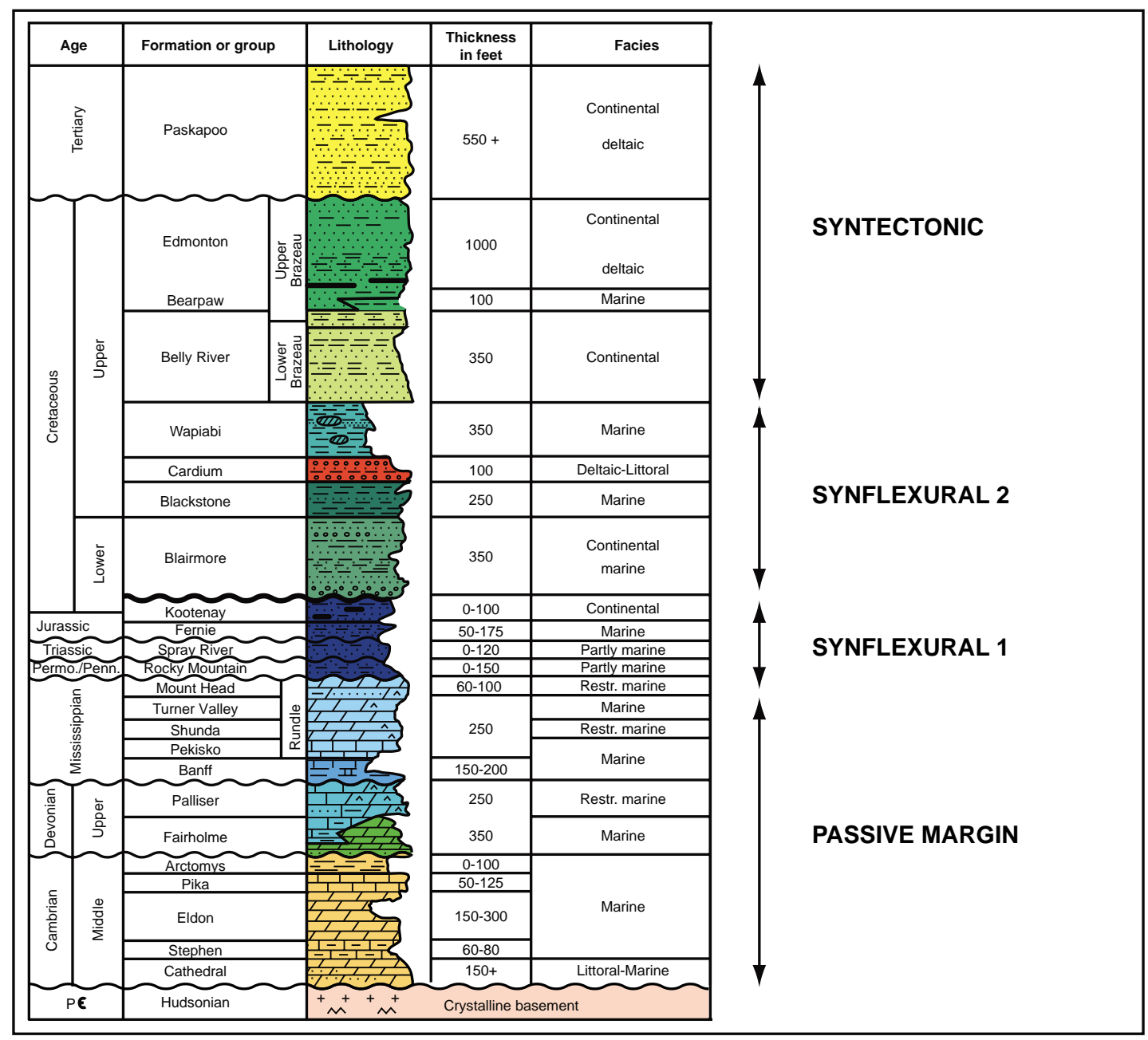

Figure 4

Synthetic lithostratigraphic column of the Alberta foothills and adjacent foreland. Notice the dominantly carbonate succession of the Paleozoic to Jurassic passive margin, and the overlying siliciclastic Cretaceous flexural sequence of the subsequent foreland basin. 
sheets made up of competent Paleozoic carbonates overlain by a thin Permo-Triassic succession that is in turn overlain by Jurassic siliciclastic formations. The eastern limit of the Front ranges is marked by the McConnell thrust, which places Middle Cambrian carbonates on top of Upper Cretaceous sandstones (Belly River formation). Farther west (Figs. 2 and 3), more internal thrust fronts such as the Exshaw, "Lac des Arcs", Rundle, Sulphur Mountain and Bourgeau thrusts occur. These faults are also interpreted to merge at depth into a common sole thrust located near the base of the Cambrian succession, just above the Precambrian crystalline basement. The western limit of the Front ranges is marked by the Castle Mountain-Simpson Pass thrust. Towards the south, the displacement on the McConnell thrust decreases progressively until it finally disappears. As the McConnell thrust dies out, shortening is transferred to Livingstone thrust, whereas the Rundle thrust is linked to the Lewis thrust. The Bourgeau thrust constitutes the westernmost thrust of the Front ranges. It can also be traced farther south to the northern end of the Fernie basin where its displacement is transferred to the McDonald thrust (Fig. 3).

- The Main ranges form a structural culmination. Its eastern part is dominantly composed of a thick succession of Cambrian carbonates and sandstones, which are intensively folded and cut by thrusts and normal faults. The eastern limit of the Main ranges corresponds to the predeformational limit of a Lower Paleozoic platform. There, the thick shallow water Cambrian to Ordovician carbonate facies of the Front ranges are overthrust by deep water shale and limestone units of the Main ranges. An important change in the deformation style is associated with this major facies change. Thus, thick competent carbonatedominated strata form massive thrust sheets in the Front ranges, while in the thicker incompetent shales and argillaceous limestones, a penetrative cleavage develops in association with disharmonic folding.

\subsection{Lithostratigraphy of Paleozoic to Mesozoic Formations, and Distribution of Potential Source Rocks and Reservoirs}

The Alberta foothills and foreland are built on the Precambrian crystalline basement of the North American craton. Middle Precambrian formations of the belt supergroup are carried in a major allochthonous thrust sheet in the southern part of the orogen, near the Canadian-United States border, but northward these rocks are replaced by Upper Precambrian Windermere supergroup and Cambrian formations which occur in the most westerly thrust sheets modeled in this Subtrap transect.

Paleozoic to Jurassic formations record the protracted evolution of the former western passive margin of the North American continent, and are dominantly composed of platformal, carbonate lithofacies in the east, which grade westward into more basinal, shaley formations (Fig. 4). Source rock intervals are best developed in the Mississippian (Exshaw formation, type II OM) and the Jurassic Nordegg formation (type II OM) and Kootenay formation coals. The primary carbonate reservoirs are found in the Mississippian carbonate ramp succession (Rundle group), but reservoirs also occur also locally in the Devonian carbonate ramp (Palliser formation). Onset of the foreland flexure and development of the foreland basin with marine transgression occurred during the Late Jurassic and Early Cretaceous (Fernie formation-Kootenay group), after an episode of exposure and deposition of continental deposits. Numerous source rock intervals have been also identified in this dominantly siliciclastic formations, i.e. in the Mannville group (type III kerogen), and in the Cretaceous Alberta group (type II kerogen). Productive sandstone reservoirs are located in various Cretaceous horizons including the Viking, Cardium and Belly River formations (Fig. 4).

\subsection{Synorogenic Sediments and Dating of the Thrust Sequence}

Synorogenic sediments are preserved only where they have been incorporated into the allochthons. Unlike in Neogene Mediterranean thrust belts like the Apennines or Albanides, it is almost impossible to detect piggyback basins in Alberta, due to the extensive syn- and postorogenic erosion that has removed up to $8 \mathrm{~km}$, or more, of sedimentary succession during both the Laramide Orogeny and the regional postorogenic epeirogenic uplift and erosion.

Constraints on the time of individual thrust displacements are provided by the age of the youngest sediments still present in the footwall strata, and by mapping cross-cutting relationships among the various thrust faults. Most inner and outer foothills thrust sheets have been offset or folded by underlying, younger thrust faults. In some regions there are cross-cutting intrusives, the age of which helps to constrain the timing of the motion on individual faults (Fig. 3).

Maturity ranks of the organic matter and apatite fission tracks measured in allochthonous units and coeval thermal modeling provide additional constraints on the timing of tectonic uplift and erosional unroofing of individual thrust sheets, especially in areas where other chronological markers are lacking.

As already mentioned in the literature (Price, 1991, 1994), the sequence of thrusting was dominantly younging eastward across the studied transect, onset of the deformation being dated as late Jurassic in the hinterland, thus accounting for the development of the Cretaceous foreland basin as a result of tectonic loading of the North American lithosphere, whereas the thrust front ultimately reached its present location during the Paleocene. Younger, Late PaleoceneMiddle Eocene ductile extension and normal faulting 
developed in the hinterland, west of the transect (Carr, 1992; Lorencak et al., 2001; Doughty and Price, 1999, 2002; Vanderheghe et al., 2003). This postcompressional crustal deformation event had no direct impact on the architecture of the Subtrap transect, although coeval asthenospheric rise in the hanging-wall of the east-dipping subduction of the Pacific oceanic lithosphere is likely to account for the postorogenic uplift and erosion observed farther to the east in the Alberta foothills, and even in the adjacent foreland autochthon (Burgess et al., 1997).

\subsection{Petroleum and Gas Occurrences}

Apart of the heavy oil accumulations found in the outer part of the foreland autochthon (Athabasca sandstones) and oil accumulated in reef related prospects of the foredeep, major gas and condensate fields are found in Paleozoic carbonates of the tectonic wedge, being inferred to have been predominantly sourced from Paleozoic formations which are currently mostly overmature or in an advanced gas window in the foothills and adjacent foreland. Oil accumulations have been found in shallower Cretaceous sandstone reservoirs in the foothills, inferred to belong to another petroleum system, linked to Mesozoic source rocks in the Alberta group, which have been locally buried down to the oil window.

\section{METHODOLOGY USED TO TRACE THE BURIAL AND THERMAL EVOLUTION OF POTENTIAL SOURCE ROCKS AND RESERVOIRS}

The integrated approach developed at IFP for the petroleum and reservoir appraisal of subthrust petroleum prospects relies on the reconstruction of the burial and temperature history of potential source rocks and reservoirs (Roure and Sassi, 1995). Kerogen transformation into hydrocarbon as well as diagenesis (quartz cementation, dolomitization, carbonate dissolution) are controlled by specific kinetics, just like any other chemical reaction, which are dependent on both time and temperature. Whether we want to predict the volume of hydrocarbon expelled from the source rocks or the amount of secondary porosity developed by dissolution, or conversely the amount of porosity reduction due to quartz cementation, these values are directly linked to the time of residence of a given source rock or reservoir at its peak temperature, which is usually also the stage when the hydrocarbons were generated and the reservoir damaged or instead enhanced (Roure et al., 2000).

1D burial and thermal history models (i.e. Genex) are still useful to calibrate the subsidence and thermal evolution of the autochthon, but they are unsufficient to simulate the tectonic duplication and lateral transport recorded in the foothills, where 2D forward kinematic models (i.e., Thrustpack), accounting for incremental thrust emplacement, and coeval erosion and sedimentation, are indeed required (Sassi and Rudkiewicz, 1999, 2000).

However, compilation of an appropriate database and formatting of the initial section are required before performing any forward kinematic and thermal modeling. For instance, the structural section needs first to be compiled from existing surface and subsurface data (geological maps with strike and dips of well dated outcropping formations, wells data, seismic profiles, the interpretation of these being ultimately converted from time to depth (implying a good understanding of the subsurface velocity model). The structural section has also to be balanced and restored in its initial, preorogenic geometry. As a result, it is necessary to extrapolate the information even in areas which are well constrained by the seismic or by the wells, as the forward kinematic simulation requires an initial geometry where all the active and future thrusts are connected at depth.

In the case of this Canadian Subtrap transect, we greatly benefited from the structural expertise of Canadian colleagues, the structural section already compiled by Price and Fermor (1985) being in the appropriate format to almost directly enter the modeling phase. Ultimately, as our objectives were not to mimic the nature but rather focus on the incidence of burial on temperature evolution of the rocks, we decided to simplify significantly the internal deformation of the Cretaceous formations in the foothills allochthon, implying that we had also to balance this simplified structural section with Locace (Morretti, 1991) before undertaking the Thrustpack forward kinematic simulations (Figs. 2 and 5).

Backstripping and fluid flow modeling have been performed along the transect subsequently, using the Ceres software. This allows the computation of the pore fluid pressure history in the Paleozoic reservoirs, as well as the study of the hydrocarbon migration and oil and gas charge of antiformal prospects of the foothills. This step of the modeling was only made possible because we could use the intermediate geometries generated from the Thrustpack modeling as target geometries for the backstripping. A detailed technical description of this ultimate step for the simulation has already been published by Schneider (2003).

\section{DATA GATHERING}

As mentioned above, we did not have to compile extensive surface and subsurface data, as the overall geometry of the structural section used for this study was already compiled by Price and Fermor (1994). Instead, we focused our data gathering on specific information and data that were required to calibrate the thermal and petroleum system modeling. This included the compilation of thermal and organic maturity data of organic rich horizons, including parameters such as Tmax, Ro and heat flow values when available from the literature and reports (Magara, 1976; Hacquebard, 1977; 


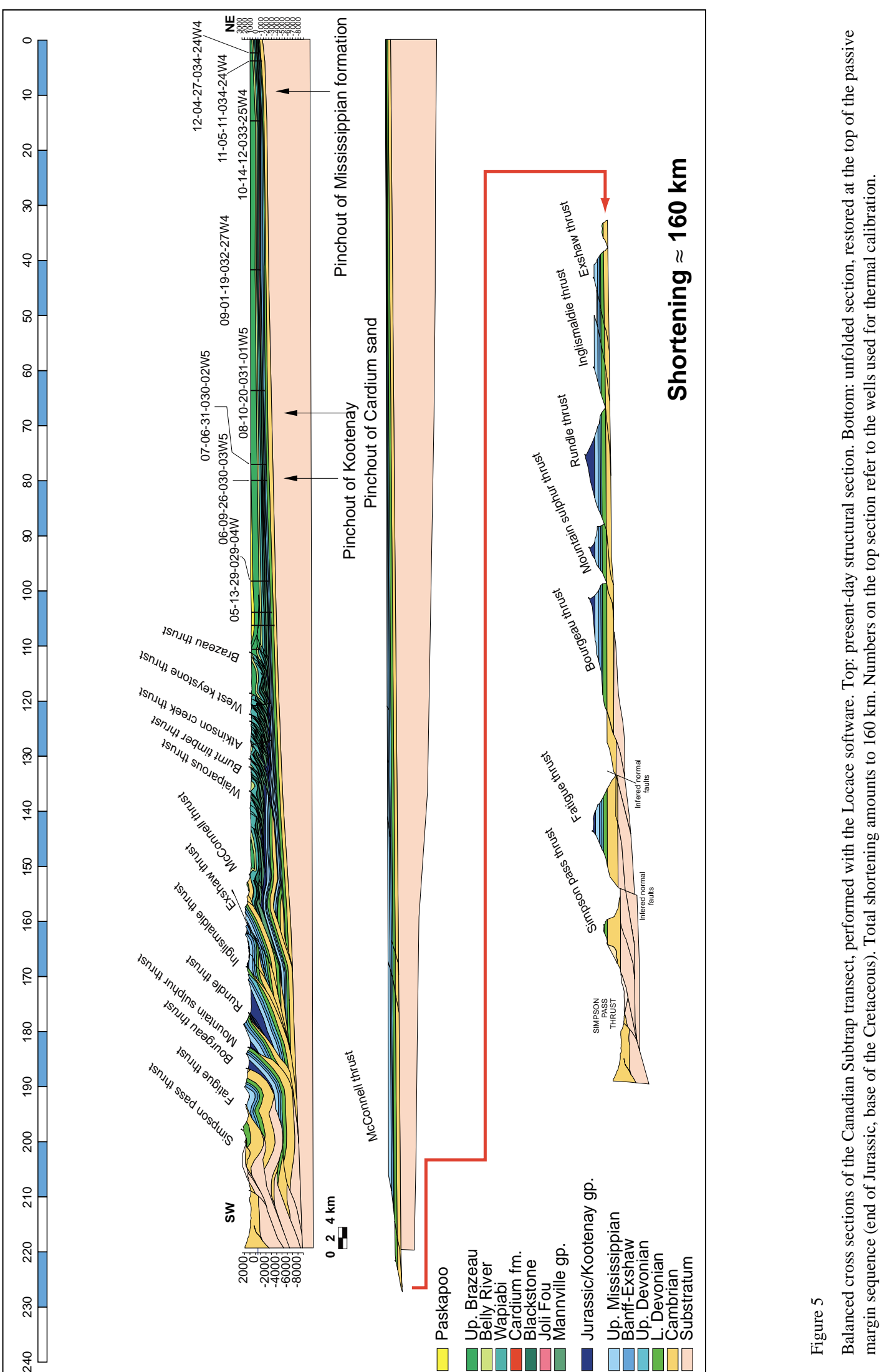




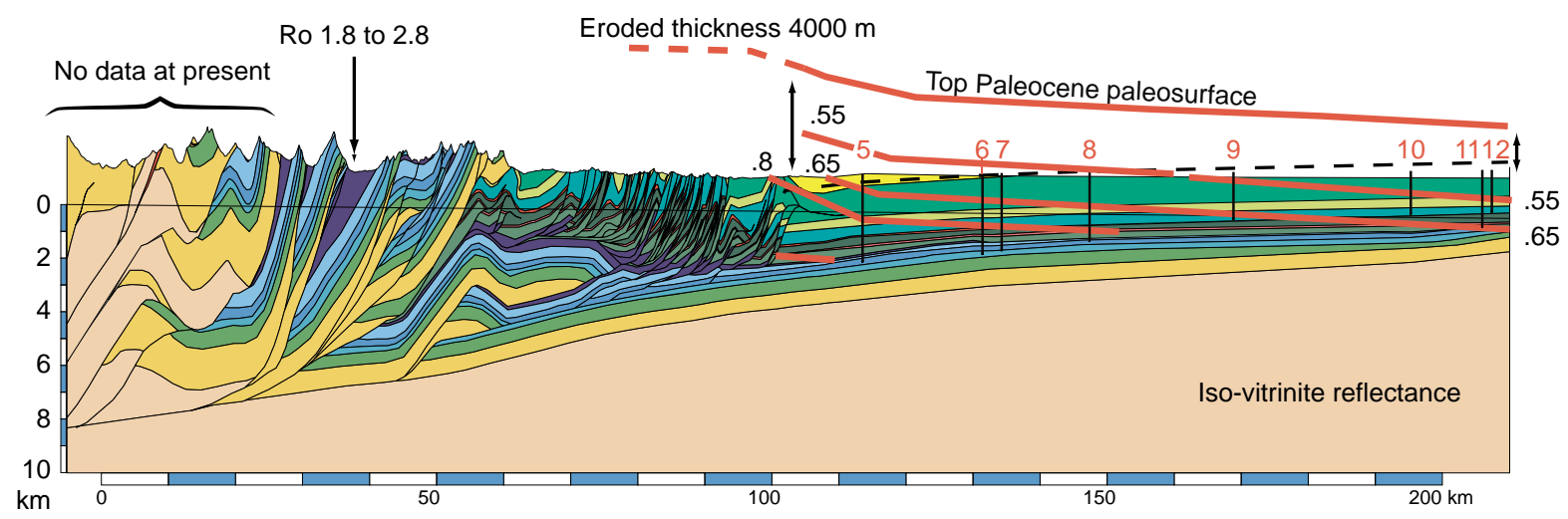

Figure 6

Compressed structural section along the Canadian Subtrap transect, outlining the iso-vitrinite profiles derived from the study of both well (foreland) and outcrop (foothills) samples.

Nurkowski, 1984; England and Bustin, 1986a; Issler et al., 1990; Majorowicz et al., 1990, 1999; Majorowicz and Jessop, 1993; Snowdon, 1997). In addition, we compiled and considered bottom-hole and drill stem test temperature or pressure data, which are routinly collected from the dozens of wells drilled near the line of section. The data compilation was enriched by reservoir parameters determined for the discovered petroleum fields like Jumping Pound and Moose Mountain. The scientific team also studied additional outcrop and core samples for both petrographic characteristics related to the paragenesis of reservoirs and for additional paleothermometric analyses.
Approximately thirty new outcrop thermal maturity indications were made along the transect, in addition to the approximately twenty thermal maturity determinations made recently in the Moose Mountain area (Ardic, 1993). In addition, eight well profiles were studied in detail and the results of the Rock-Eval-TOC pyrolysis maturity parameters were used to constrain estimates of paleogeothermal gradient and eroded section (Benaouali, 2000; Figs. 6, 7 and 8). Finally approximately 100 petroleum well temperature data points were considered in the region $(100 \times 100 \mathrm{~km})$ surrounding the studied transect. All of this complemented and augmented an extensive regional thermal maturity data
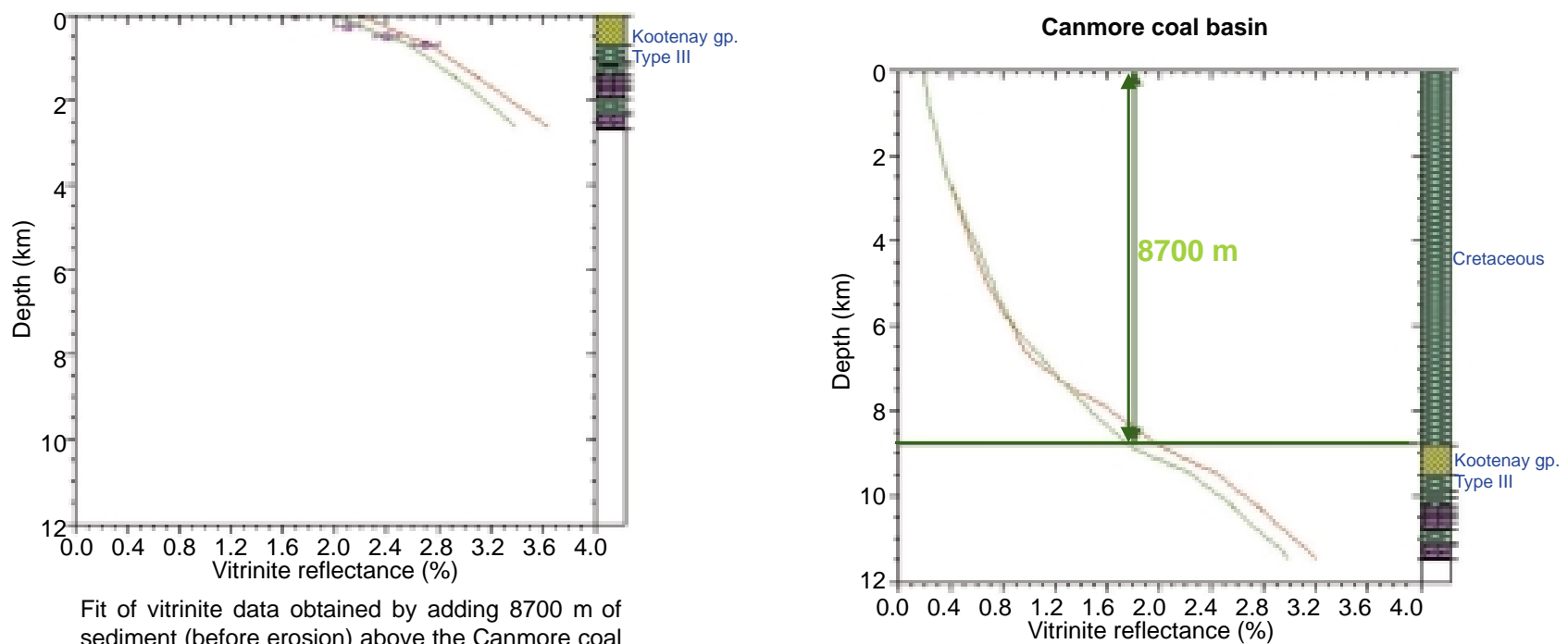

Fit of vitrinite data obtained by adding $8700 \mathrm{~m}$ of sediment (before erosion) above the Canmore coal basin (Hughes, 1987).

Figure 7

Fictive well modeled with Genex in the Canmore Jurassic coal basin, currently accreted into the tectonic wedge. Model result accounts for up to $8.7 \mathrm{~km}$ of missing Cretaceous formations, which became eroded partly during the Late Cretaceous-Paleocene thrust emplacement, and partly during postorogenic uplift of the Cordillera. 


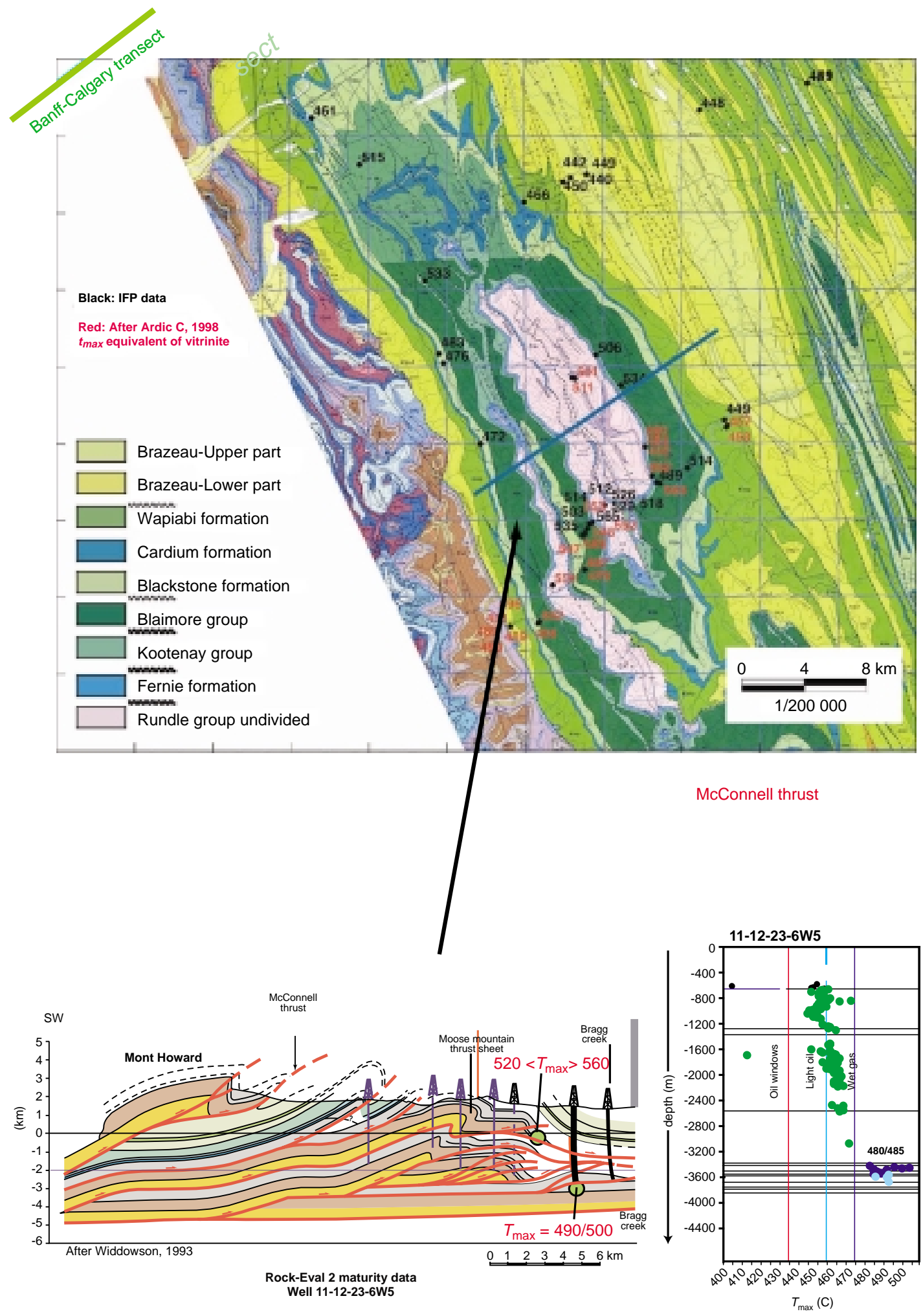

Figure 8

Maturity ranks of the organic matter in the vicinity of the Moose Mountain antiformal stack. Top: regional map with location of outcrop samples (Tmax equivalent of Ro vitrinite, from Ardic, 1998, and Tmax measurements on samples, Faure et al., 2002a). Bottom: cross section of the Moose antiformal stack with distribution of Tmax profiles from well samples (Widdowson, 1993; Snowdon, 1997). 
set (Magara, 1976; Hacquebard, 1977; Nurkowski, 1984; England and Bustin, 1986a; Issler et al., 1990; Majorowicz et al., 1990).

\section{FORELAND FLEXURE, EROSION, FORWARD KINEMATIC AND THERMAL MODELING}

\subsection{Burial Curves}

Burial curves have been computed with Genex for a number of wells of the foreland autochthon, that reached Devonian and Mississippian horizons (Figs. 7, 8 and 9). They record the main geodynamical events which affected the North American craton and the Cordillera since the Cambrian.

A strong increase of the subsidence rate is observed during the late Devonian (Fig. 10). This has been usually interpreted as a far field effect of the Antler Orogeny, with development of a foreland lithospheric flexure. Other interpretations would rather consider here a thermal event (Osadetz et al., 2004), coeval with renewed rifting farther to the south, that would have changed the thermomechanical equilibrium of the North American lithosphere at this stage, without involving the need for any tectonic load or lithospheric buckling in a compressional regime.
After a long period of quiescence, tectonic subsidence resumed during the Cretaceous, foreland lithospheric flexure then developing in the Canadian basin as a result of tectonic loading in the hinterland.

Postorogenic unflexing and erosional unroofing are recorded in the wells from the autochthonous foreland, accounting for a progressive decrease of the burial during the Cenozoic. This phenomenon is likely to occur also in the foothills, where it is overimposed on earlier, synthrusting episodes of uplift and erosion.

\subsection{D Thermal Modeling and Construction of the Erosional Profiles}

Erosional profiles have been computed by means of 1D Genex thermal modeling in the wells from the autochthonous foreland, using Tmax and Ro values and BHT (Fig. 11). These profiles have been extended toward the hinterland using fictive wells in the main thrust units of the foothills and hinterland where Tmax or Ro values were also available in either Mesozoic or Paleozoic formations, or both.

Up to $8.7 \mathrm{~km}$ of missing Cretaceous formations have thus been inferred in the vicinity of Canmore, based on the maturity ranks of Jurassic coal measures of the Kootenay formation (Figs. 7 and 11).

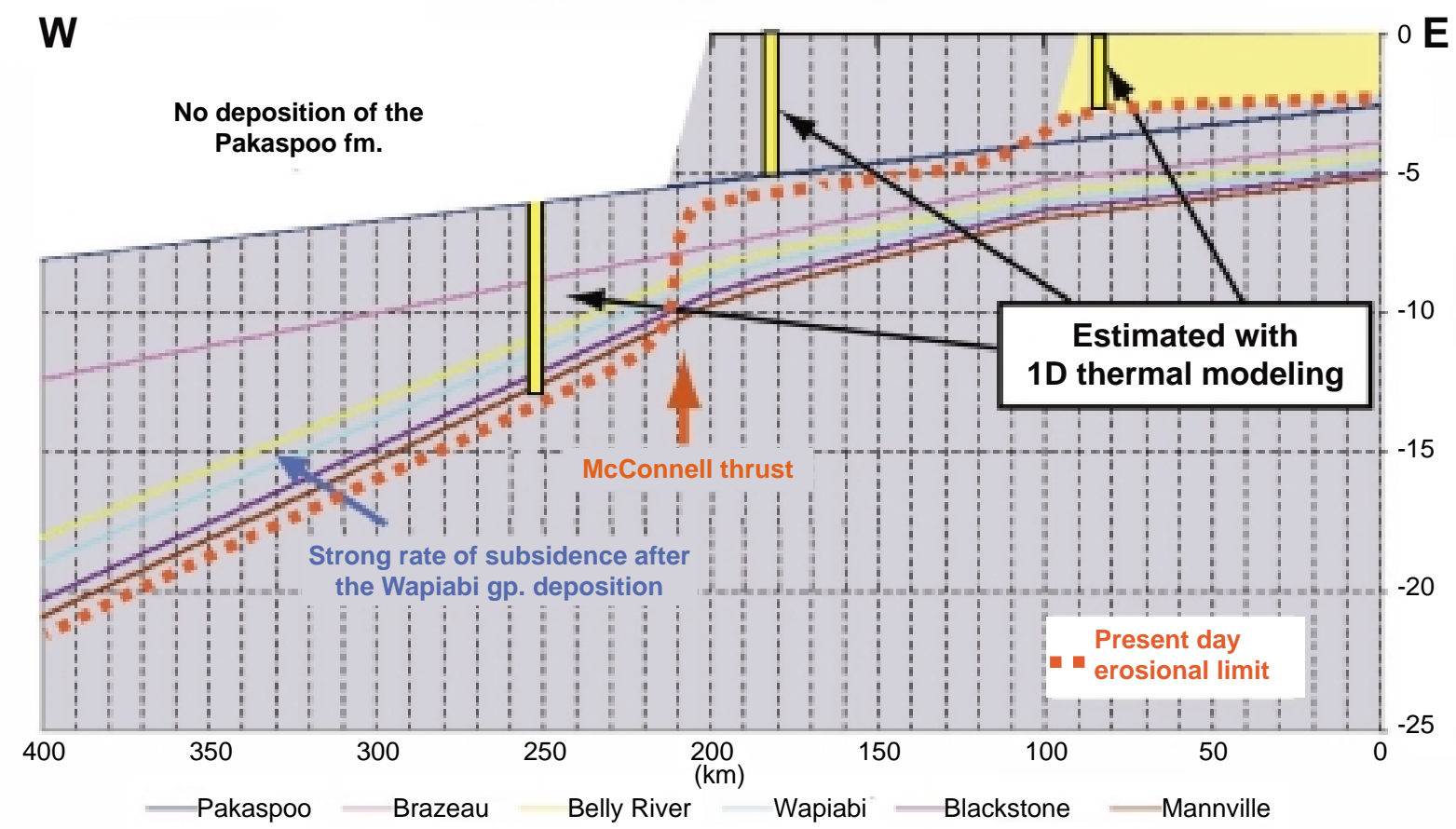

Figure 9

Prethrusting sedimentary thicknesses of the Cretaceous foreland basin, computed from 1D Genex thermal modeling. 

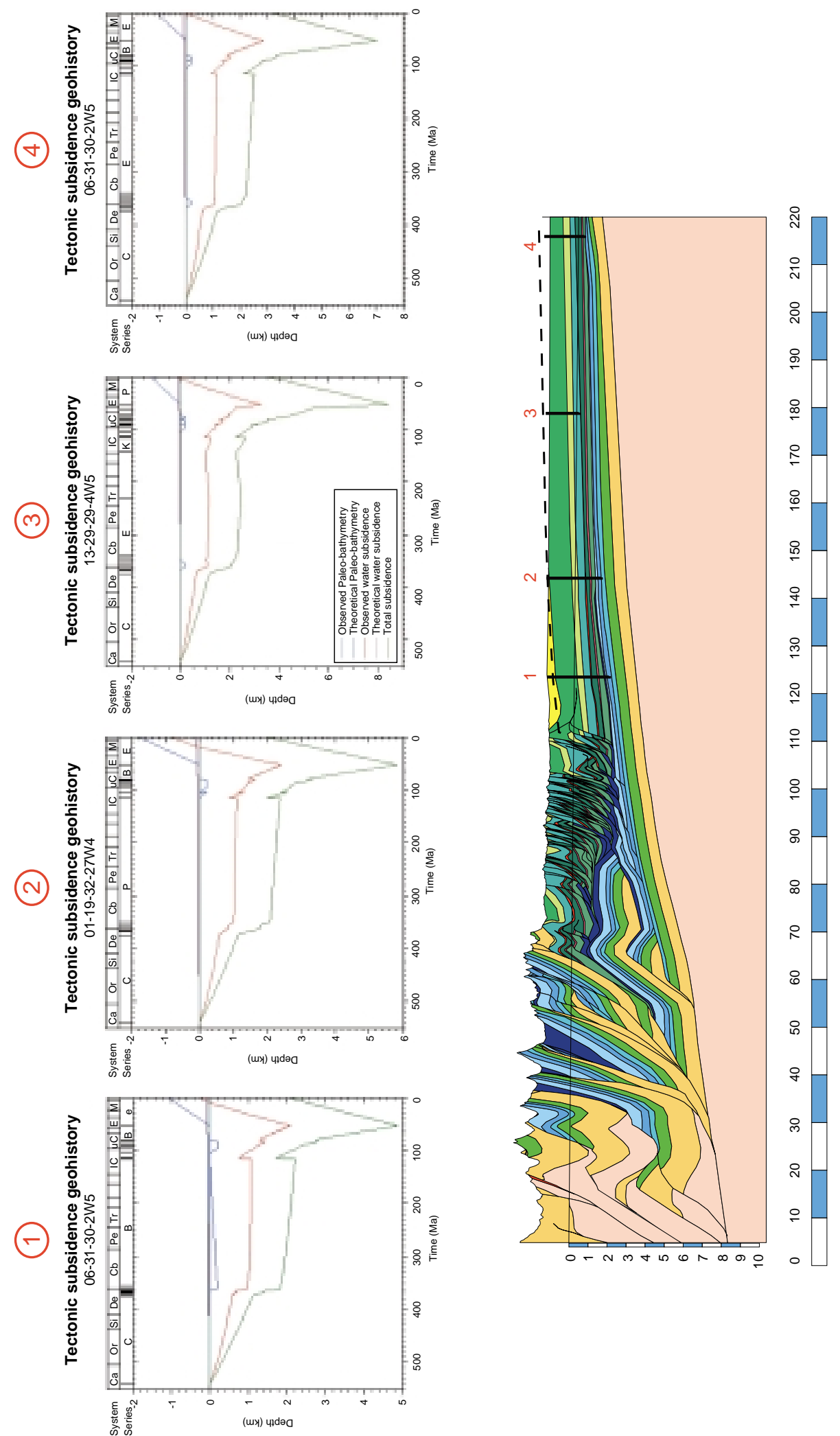

Figure 10

Typical subsidence curve of foreland wells, outlining an anomalous subsidence rate during the Late Devonian, Carboniferous to Late Jurassic quiescence, onset of the flexural subsidence during the Cretaceous (as a result of tectonic loading in the hinterland), and Cenozoic unflexing and uplift. 


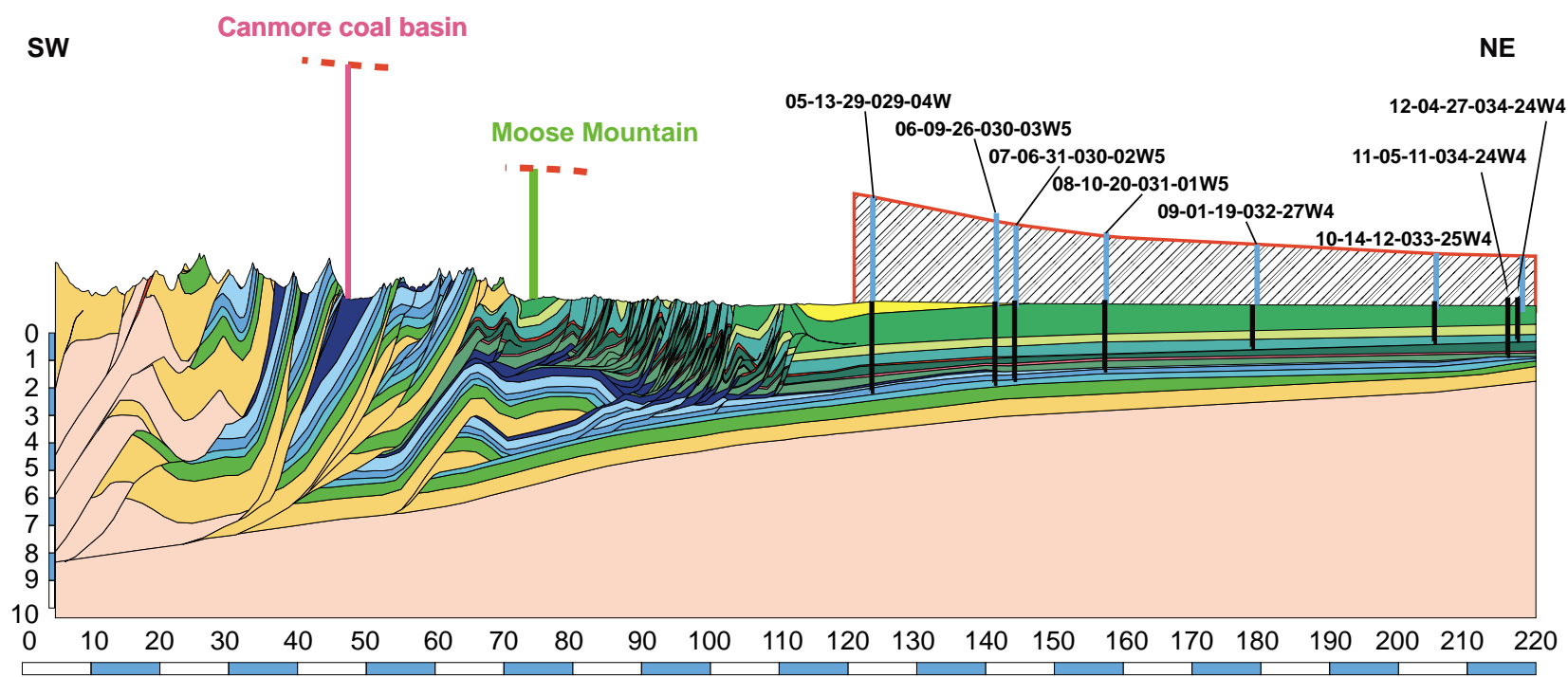

Figure 11

Cumulative eroded thicknesses computed from 1D Genex thermal modeling along the transect. Part of the erosion in the foothills was coeval with thrust emplacement, whereas all the erosion in the autochthonous foreland relates to postorogenic unflexing and uplift.

\subsection{D Forward Kinematic and Thermal Modeling}

Erosional profiles and subsidence curves computed with Genex have been used to reconstruct the initial thickness of Cretaceous formations along the section, thus implementing the geometry of the initial, preorogenic section on which forward Thrustpack kinematic modeling was ultimately applied (Fig. 12a, b and 13).

It seems that Tmax and Ro values and bottom hole temperatures measured in the foreland wells have been used to calibrate the basal heat flow using 1D Genex simulations.

The mean geothermal gradient fluctuates between $21^{\circ} \cdot \mathrm{km}^{-1}$ in the inner part of the foothills up to $36^{\circ} \cdot \mathrm{km}^{-1}$ in the more external part of the foreland crossed by the transect (i.e., in the Garrington field in the Interior plains). These values are similar to published values for Northern Alberta (Majorowicz et al., 1999). However, the change from a low geothermal gradient in the foothills to a higher gradient in the central part of the foreland basin remains questionable, unless it relates to local cooling of the shallow carbonate allochthon by means of meteoric water circulations.

The mean temperature of Mississippian reservoir strata in front of the foothills is close to $90^{\circ} \mathrm{C}$. This value was the ultimate temperature target we used for the forward modeling. The top basement heat flow necessary to obtain a good fit with the present-day temperature is about $40 \mathrm{~mW} \cdot \mathrm{m}^{-2}$. This is similar to the heat flow computed with the presentday temperature in the same region (Bachu and Burwash, 1991). As no rifting event affected the North American craton since the Cambrian, or eventually the Devonian, we assumed a constant heat flow value through times for the subsequent 2D Thrustpack thermal modeling.

\section{MATURITY EVOLUTION OF POTENTIAL SOURCE ROCKS ALONG THE TRANSECT}

Once the forward kinematic and thermal simulations has been validated against current distribution of maturity ranks of organic rich samples and bottom hole temperatures, we could analyze in detail the past and current distribution of maturity windows with respect to the location of potential prospects and timing of their structural closures (Fig. $14 a$ and $b)$.

Although the Thrustpack thermal computation was performed using purely conductive heat transfers, it is assumed to be sufficient here and quite representative of the evolution of low permeability medium such as source rock intervals and the overburden, which are made up of dominantly shaley horizons. Temperature in the high porosity-high permeability reservoirs and nearby vertical fault conduits may account for local discrepancies between the measured values in these rocks and the overburden, due to either rapid vertical escape of hydrothermal fluids (higher temperatures in the pores compared to the overburden) or on the opposite, to the downward circulation of meteoric fluids (lower temperatures in the reservoir compared to the overburden).

Present distribution of the maturity windows was obtained quite early in both the foreland and the allochthon, prior to the onset of postorogenic regional unflexing and erosion. They thus reflect a frozen, fossil distribution, recent 
Stage 115 Ma: Mannville base
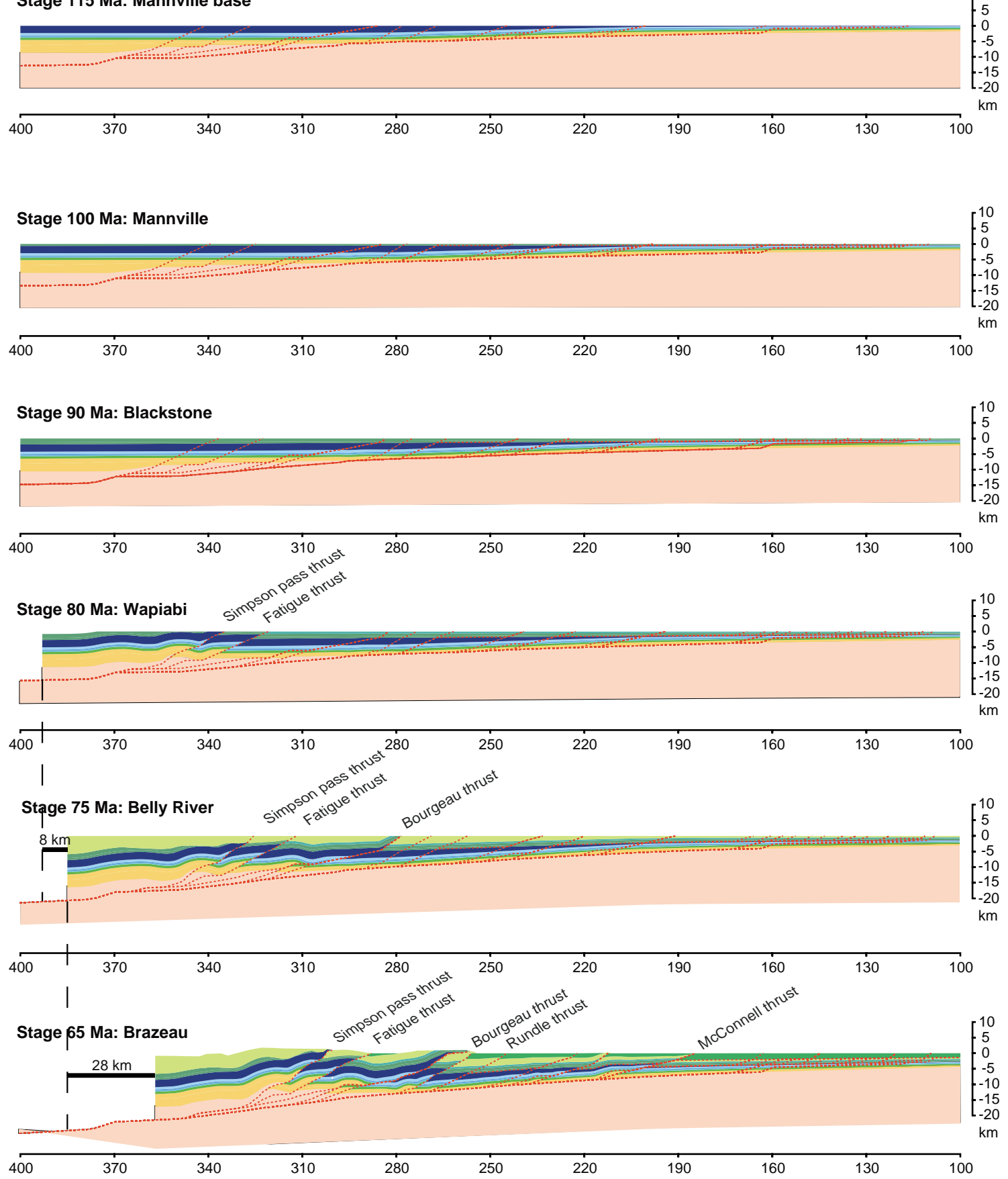

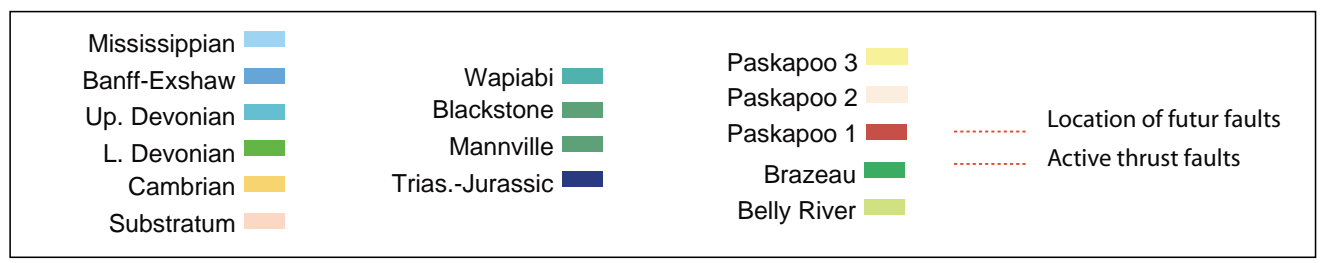

Figure 12a

Serial sections summarizing the successive evolutionary stages computed during the Thrustpack forward kinematic modeling, from the end of the first flexural basin period (Upper-Jurassic-Lower Cretaceous) onward. 

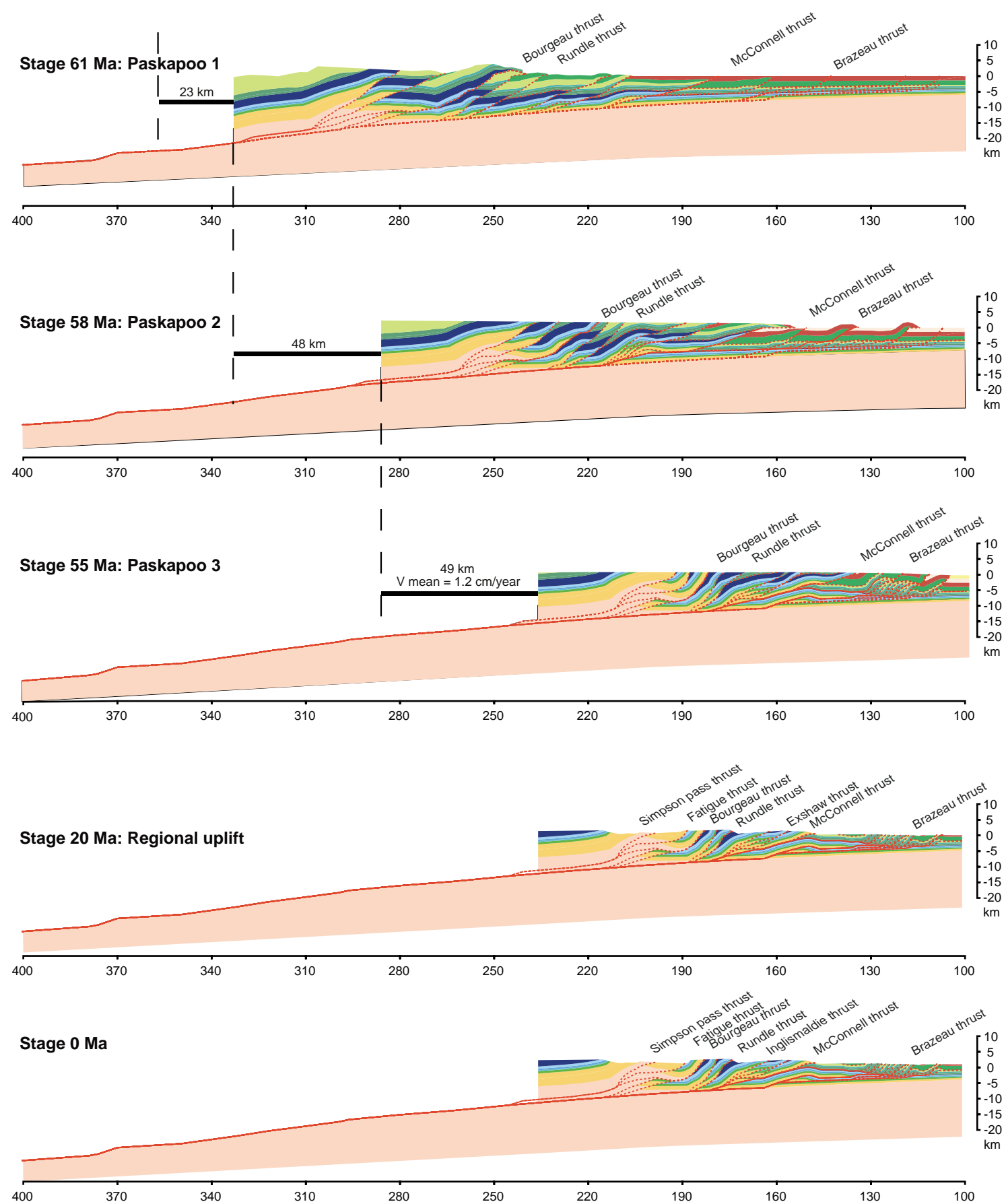

\begin{tabular}{|c|c|c|c|}
\hline $\begin{array}{l}\text { Mississippian } \\
\text { Banff-Exshaw } \\
\text { Up. Devonian } \\
\text { L. Devonian } \\
\text { Cambrian } \\
\text { Substratum }\end{array}$ & $\begin{array}{c}\text { Wapiabi } \\
\text { Blackstone } \\
\text { Mannville } \\
\text { Trias.-Jurassic }\end{array}$ & $\begin{array}{c}\text { Paskapoo } 3 \\
\text { Paskapoo } 2 \\
\text { Paskapoo } 1 \\
\text { Brazeau } \\
\text { Belly } \\
\text { River }\end{array}$ & $\begin{array}{l}\text { Location of futur faults } \\
\text { Active thrust faults }\end{array}$ \\
\hline
\end{tabular}

Figure $12 b$

Serial sections summarizing the successive evolutionary stages computed during the Thrustpack forward kinematic modeling, from the end of the first flexural basin period (Upper-Jurassic-Lower Cretaceous) onward. 

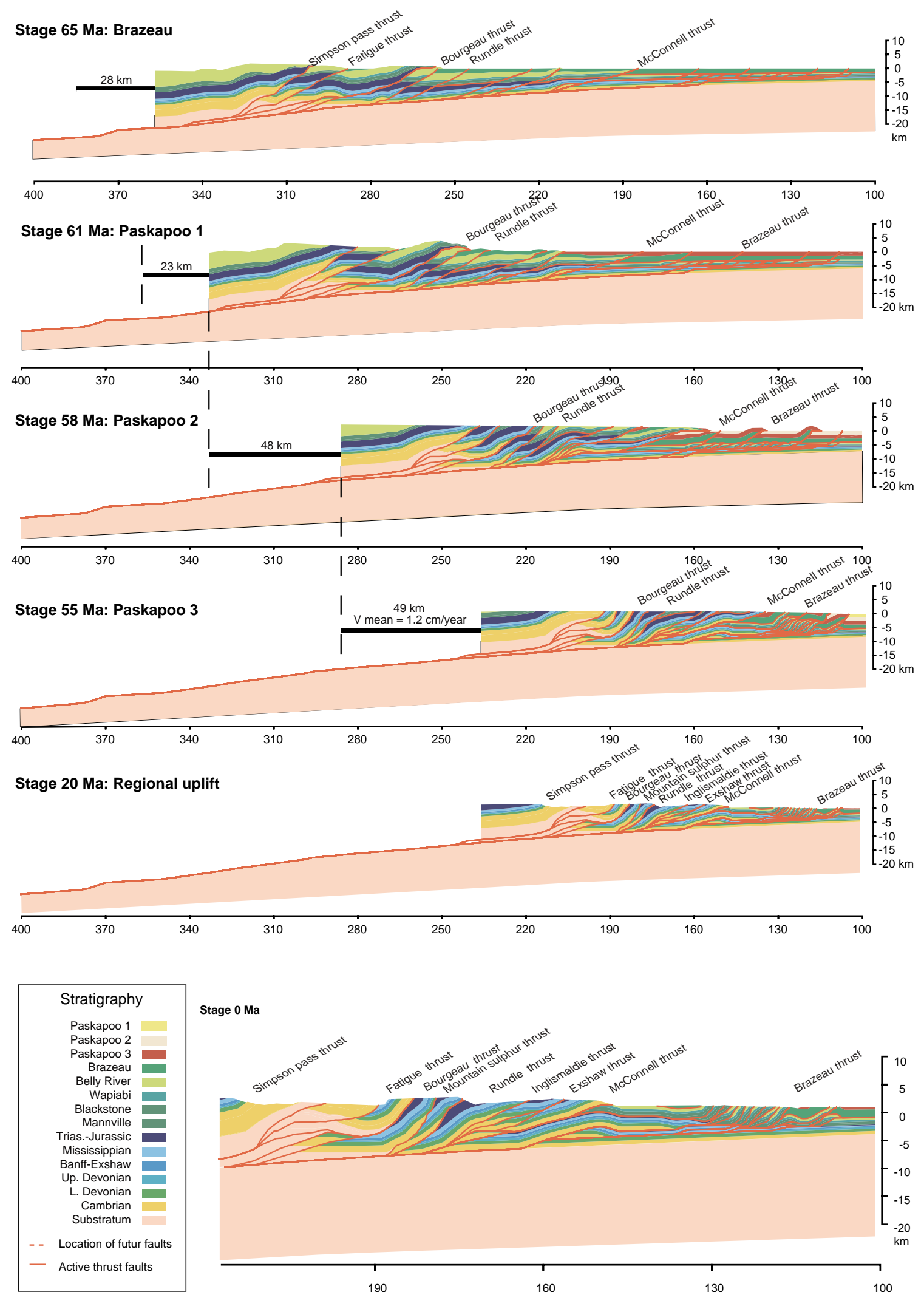

Figure 13

Enlarged result sections accounting for the final thrust emplacement of the foothills units. 
115 Ma: Mannville fm. base

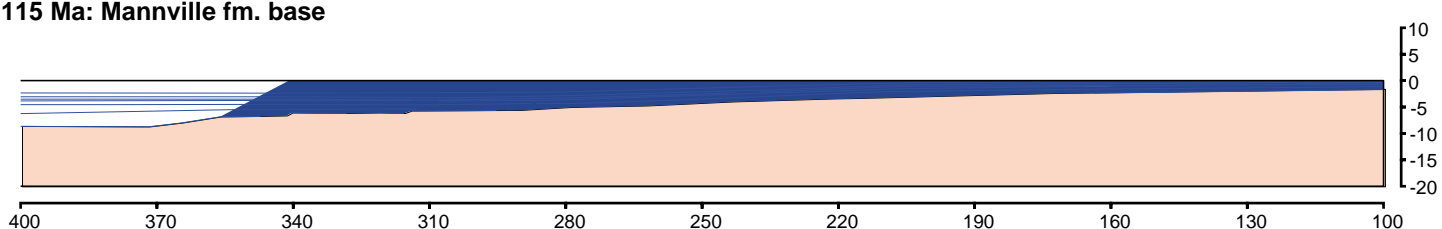

100 Ma: Mannville fm.

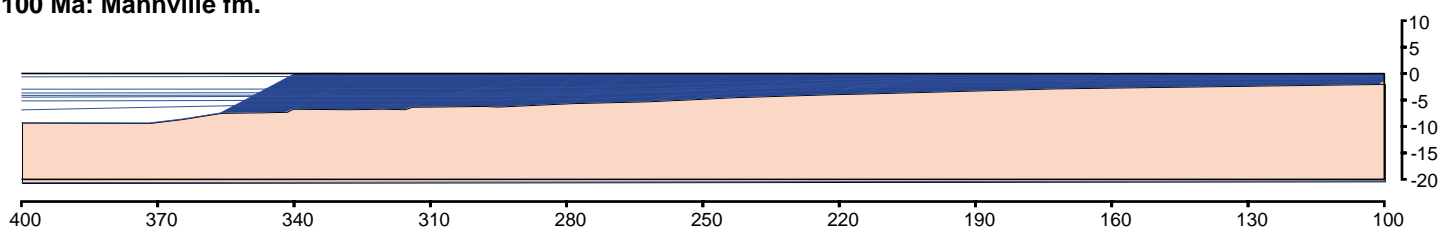

90 Ma: Blackstone fm.


75 Ma: Belly River fm.
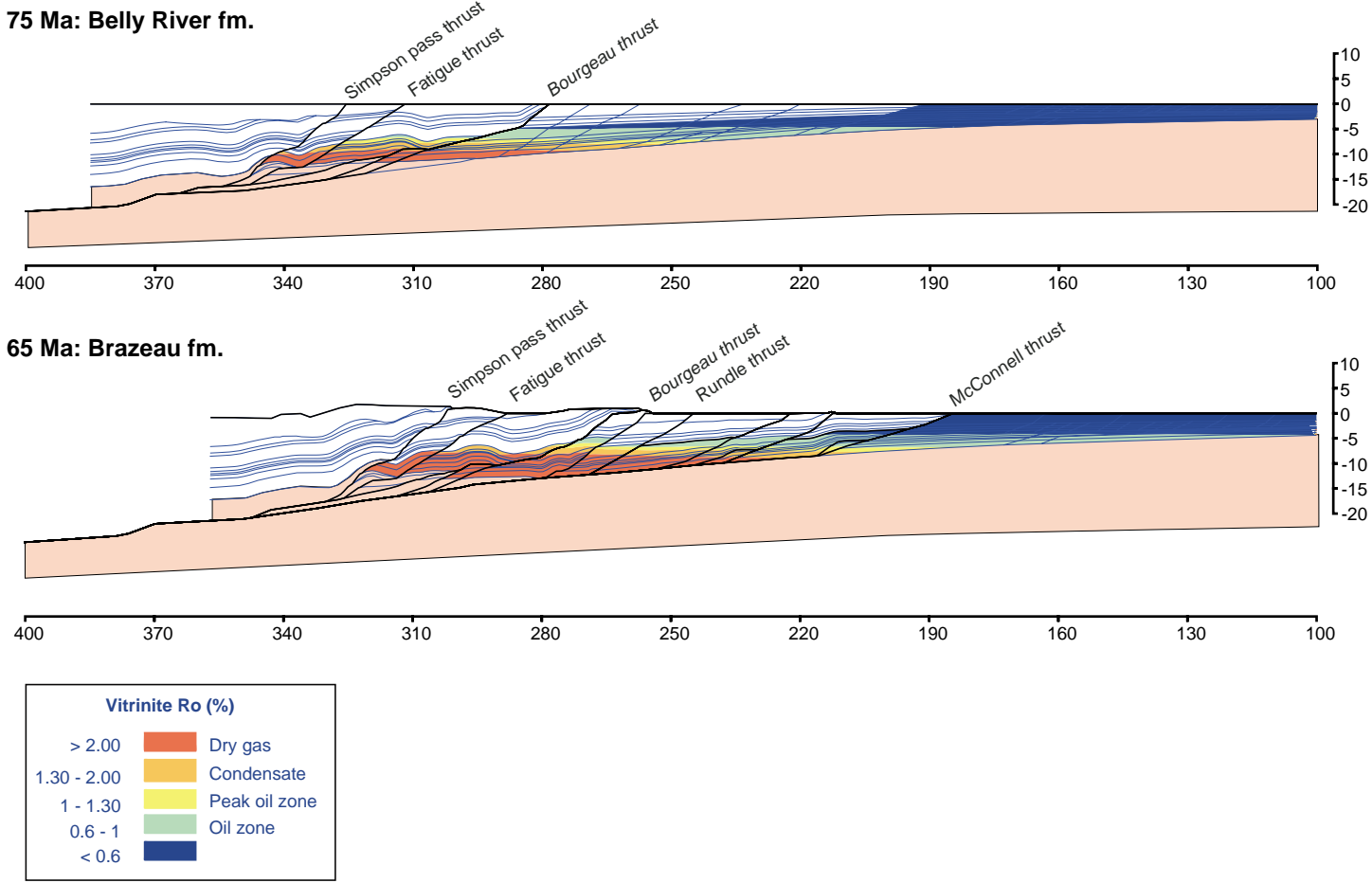

Not to scale

Figure 14a

Serial sections outlining the evolution of the maturity rank of potential source rocks through times, as computed with Thrustpack. Notice the lateral and vertical migration of oil and gas kitchens through times. 


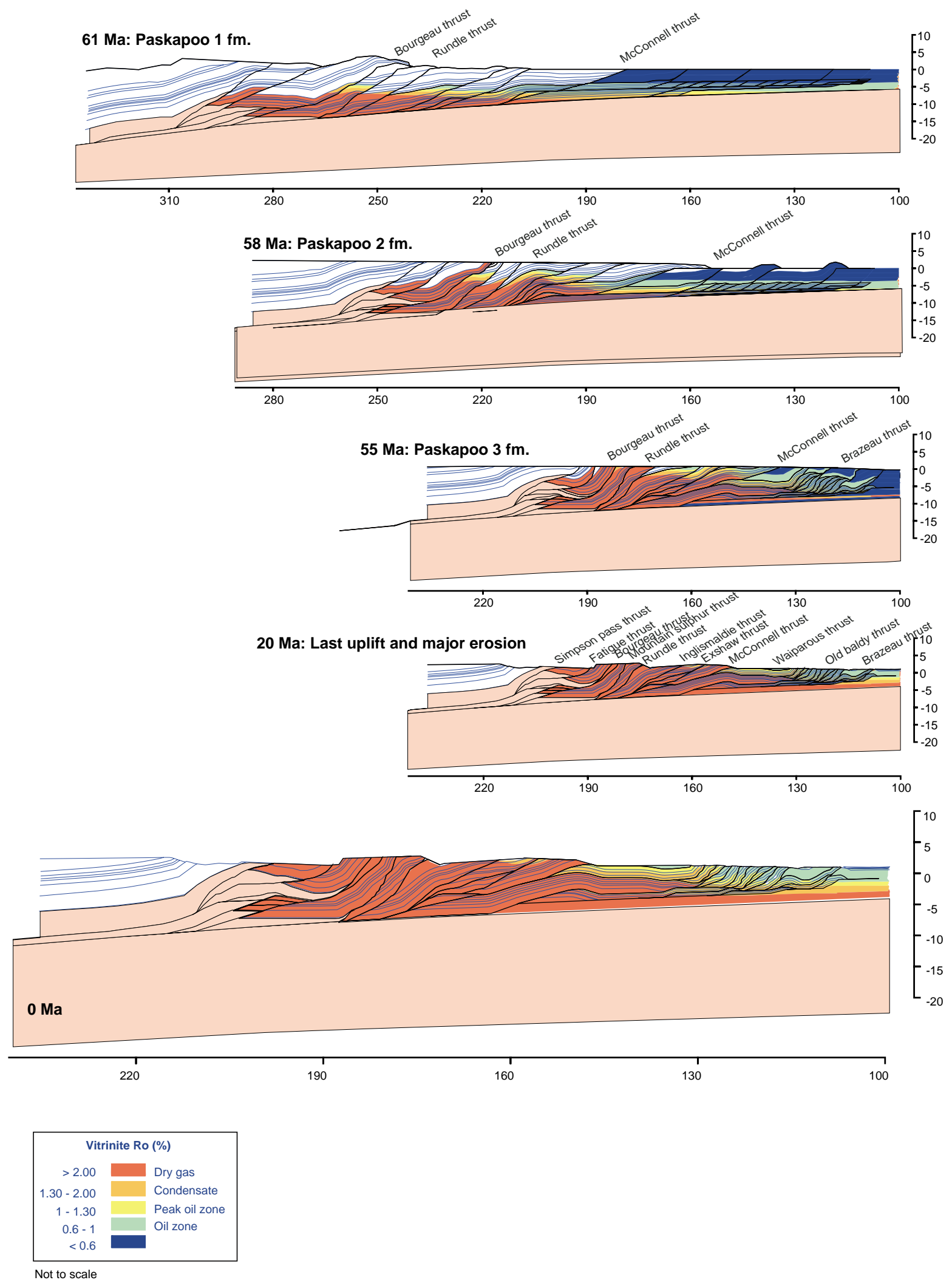

Figure $14 \mathrm{~b}$

Serial sections outlining the evolution of the maturity rank of potential source rocks through times, as computed with Thrustpack. Notice the lateral and vertical migration of oil and gas kitchens through times. 
hydrocarbon generation, if any, being clearly slower than the one which could occur earlier at higher temperatures.

Most of the allochthon reached the gas window prior to the end of the thrust emplacement, whereas only Mesozoic formations preserved their oil potential until the end of the deformation in the foothills domain and forelandward.

\section{REGIONAL FLUID FLOW, PORE FLUID PRESSURE EVOLUTION AND HYDROCARBON CHARGE OF POTENTIAL RESERVOIRS}

Regional fluid flow and pore fluid pressure evolution in Paleozoic carbonate reservoir, as well as migration trends and hydrocarbon charge of the Paleozoic and Cretaceous reservoirs, have been computed using the new Ceres tool developed by IFP for 2D basin modeling in complex areas (Schneider, 2003).

\subsection{Regional Fluid Flow}

Ceres modeling has provided valuable information on the overall fluid flow regime across the Alberta foothills and adjacent foreland, and its evolution through time (Fig. 15). Velocity of the fluids expelled forelandward from Paleozoic reservoirs reaches its peak immediately prior to their tectonic accretion into the allochthon. This phenomenon, already qualitatively assumed and described as the squeegee effect by Machel and Cavell (1999), can thus now be quantified.

Velocity measured in the reservoir remains quite low before and after this almost instant squeegy influx, implying diagenetic reactions predating or postdating this unique event of open circulation occurred in a relatively closed system without the advection of exotic fluids.

Fluid flow computed in shallower, Cretaceous sandstone reservoirs of the foredeep basin are locally moving in the opposite direction, i.e. from the foreland toward the thrust belt. Such phenomenon was already described by Bachu (1999). The origin of this flow is related to a secondary topographic recharge area in the eastern part of the section, where Cretaceous sandstones (aquifers) crop out.

Results of the Ceres modeling are also consistent with the occurrence of the local advection of hot hydrothermal fluids in the allochthon, accounting for instance for the occurrence of hot springs in the vicinity of major thrust faults near Banff.

\subsection{Pore Fluid Pressure Evolution}

Local and instant pore fluid pressures in the Paleozoic carbonate reservoirs along the transect are controlled by the location and elevation of hydraulic heads of meteoric water entering the system in the foothills, and the overall permeability of the foreland formations, either conduits or seals. In nature, excess of pore pressure is likely to be progressively dissipated by a slow diffusion of the fluids in the overburden, or by episodic events of hydraulic fracturing, which are likely to damage the seal capacities of the overburden.

For example, in the Mississippian dolomite reservoirs of the subthrust prospects, the hydraulic head evolution shows 4 stages:

- from time of deposition to $100 \mathrm{Ma}$, the hydraulic head is close to $0 \mathrm{MPa}$;

- from 100 to $59 \mathrm{Ma}$ (e.g. during tilting and thrusting), the hydraulic head increased up to $10 \mathrm{MPa}$;

- from 59 to $20 \mathrm{Ma}$ (e.g. during the main erosional episode), the hydraulic head decreased;

- during the last $20 \mathrm{Ma}$ (e.g. during recent uplift), the hydraulic head increased again.

One important remark is that the present day fluid flow pattern is completely disconnected from the one computed before the erosion. Indeed, during tilting and thrusting, fluid flow was driven by both compaction disequilibrium and topography, while it is only driven by topography at present day.

\subsection{Hydrocarbon Charge of Potential Reservoirs}

The evolution of two distinct potential source rocks has been investigated during the Ceres modeling, namely the Mississippian Exshaw formation (organic matter type II; Fig. 16a), and the Cretaceous Alberta group shale succession (organic matter type II intervals; Fig. 16b). Results help to control the overall long range migration trends between the foredeep and the foreland, and shorter migration trends within the foothills.

In order to better differentiate the contribution of each source rock family in the hydrocarbon charge of foothills prospects, 3 distinct simulations have been carried out with Ceres:

- one simulation with only the Exshaw formation as a source rock (Fig. 16a);

- another simulation with all the potential source rock formations but the Exshaw (Fig. 16b);

- and a last simulation with all the potential Paleozoic and Mesozoic source rocks (Fig. 16c). Results clearly indicate that Exshaw is the main source rock contributing to the hydrocarbon charge of Mississippian reservoirs. For the Cretaceous sandstone reservoirs however, results remain inconclusive as they were not defined precisely enough in the initial section, primary objectives of the study being focused on Paleozoic carbonate reservoirs only.

The hydrocarbon charge (sat. $>1 \%$ ) of deep subthrust prospects began between 63 and 59 Ma, i.e. slightly later than onset of primary migration and expulsion from underlying source rocks, which occurred between 75 and $65 \mathrm{Ma}$, due to the expulsion saturation threshold that was 


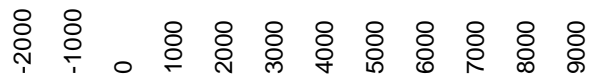

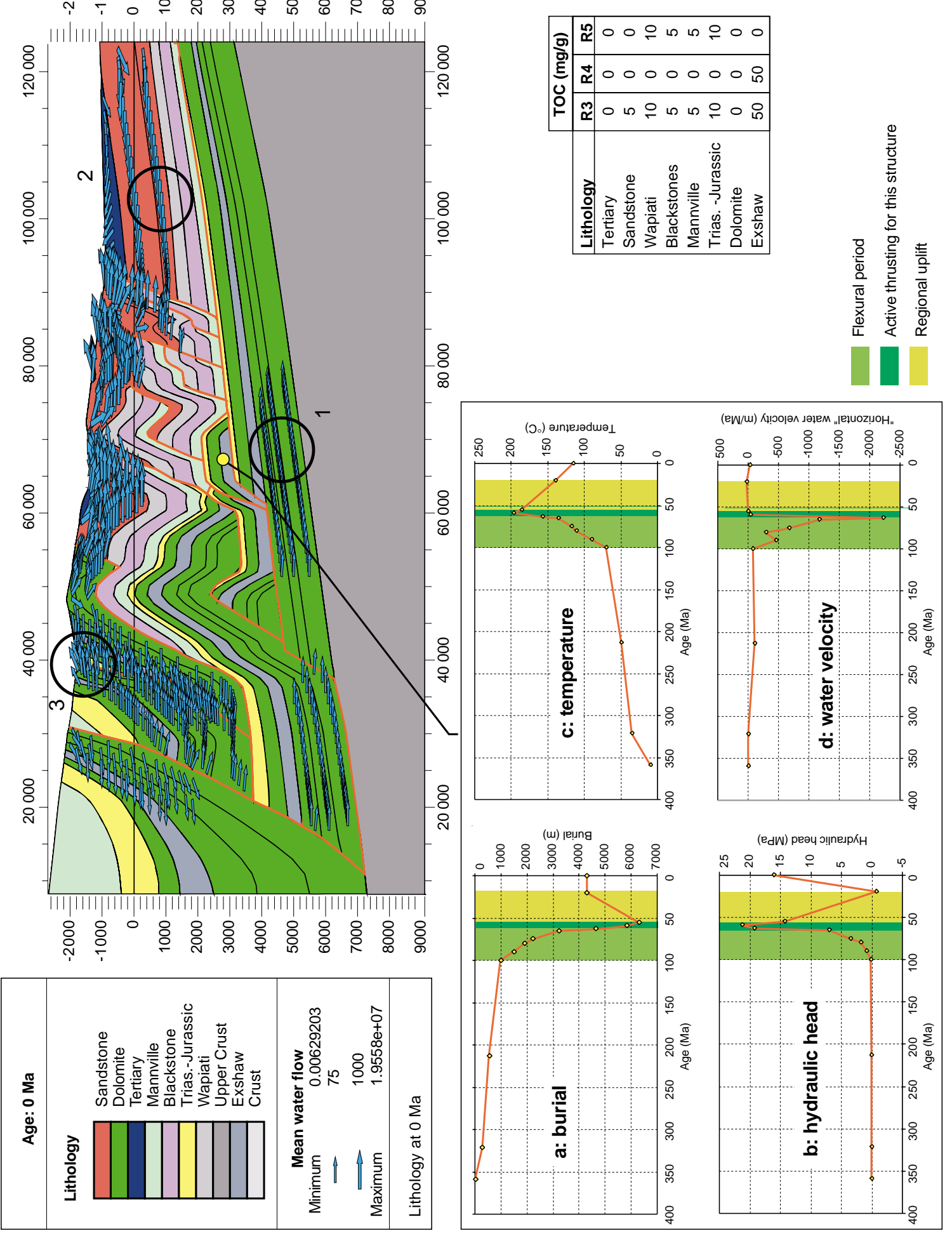

बิ宀

50

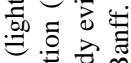

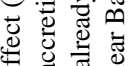

品 芩言

过 농

定焉

踏

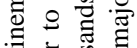

竞边骂

合运

긍 웡

就

记

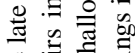

흘 के

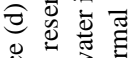

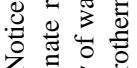

乙。

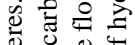

U :

声焉

उ

章过

品品

जि

寻它㤩

㐘 త্

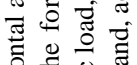

氖宅

的政

능 荢

ह 을

垴.

西

可 0

웅을 중

$\Xi$ 政

궁 은 흥

范造

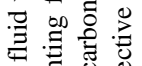

宅

ธิ

跣

흘웡

:

完表骂 宗

苛䒕会

늘

형

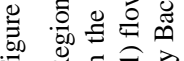




\section{Transformation ratio}

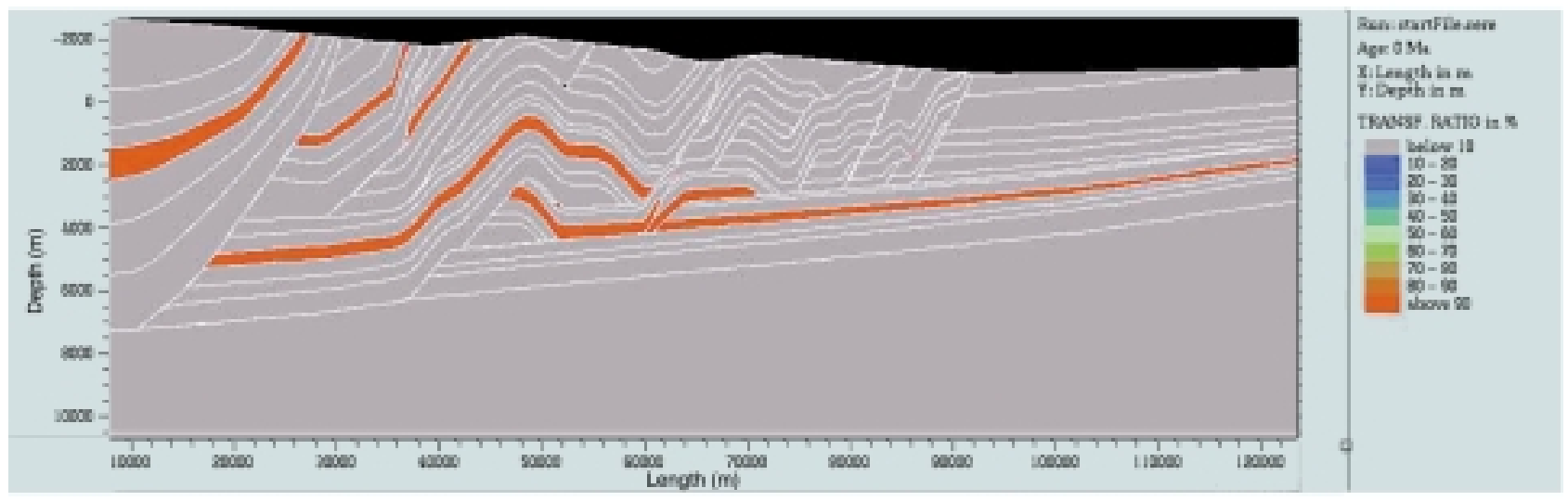

\section{Oil saturation}

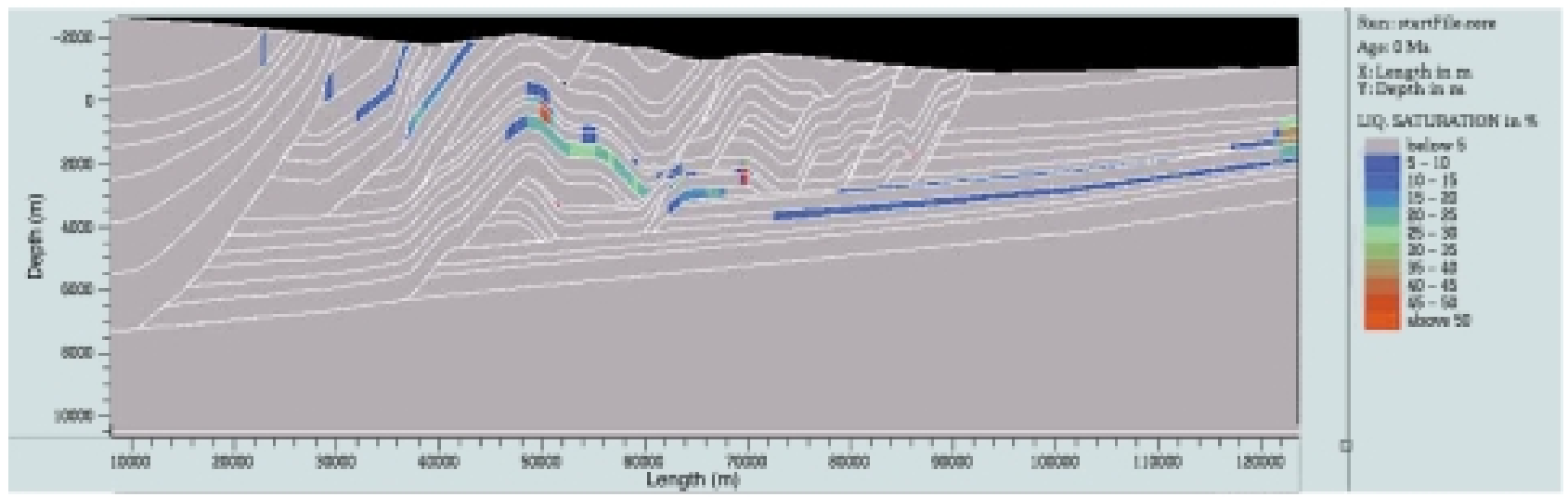

\section{Gas saturation}

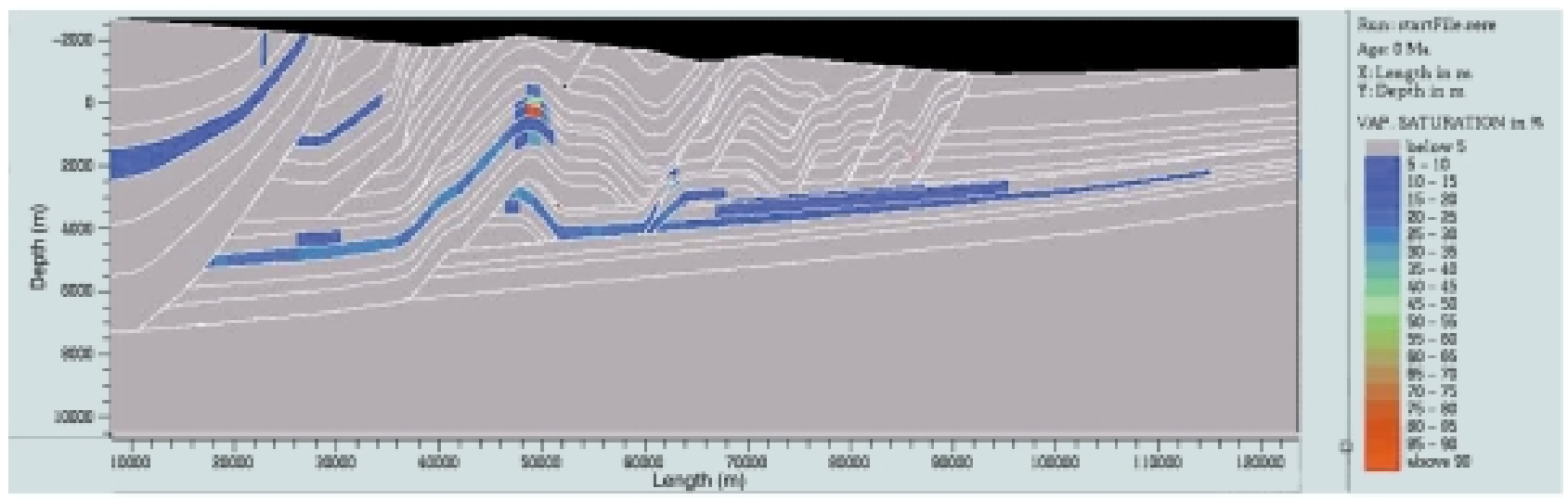

Figure 16a

Maturity evolution of the Exshaw formation alone, and coeval hydrocarbon charge of potential Devonian and Mississippian carbonate foothills reservoirs, as computed with Ceres. 


\section{Transformation ratio}

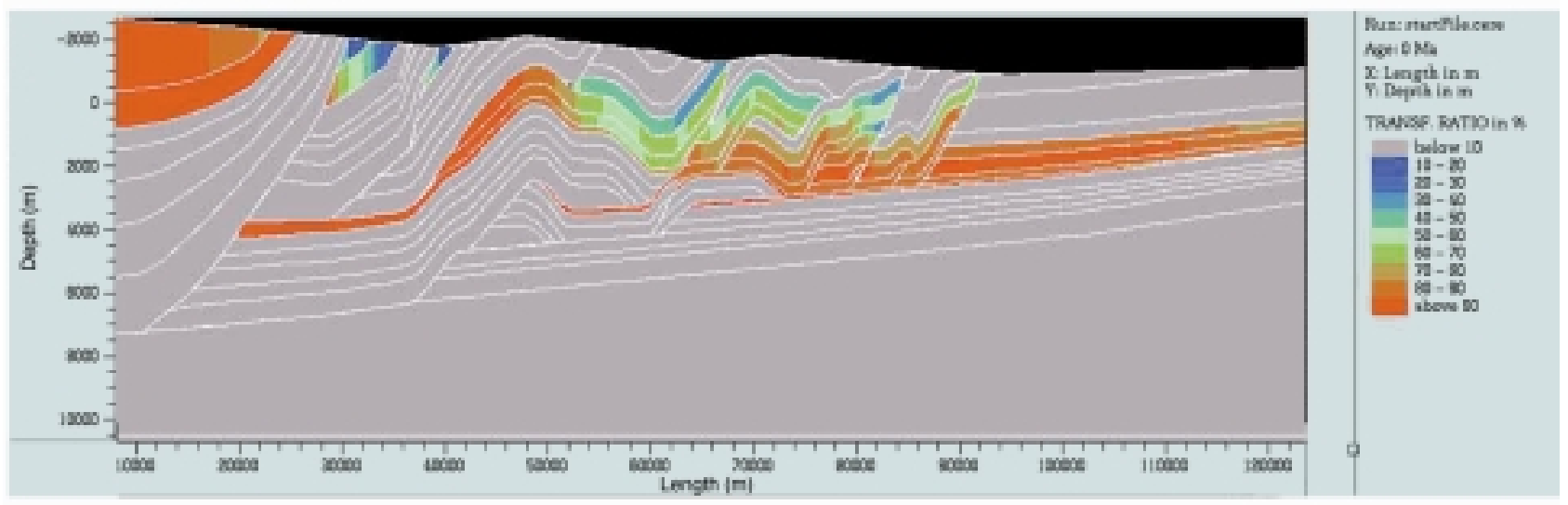

\section{Oil saturation}

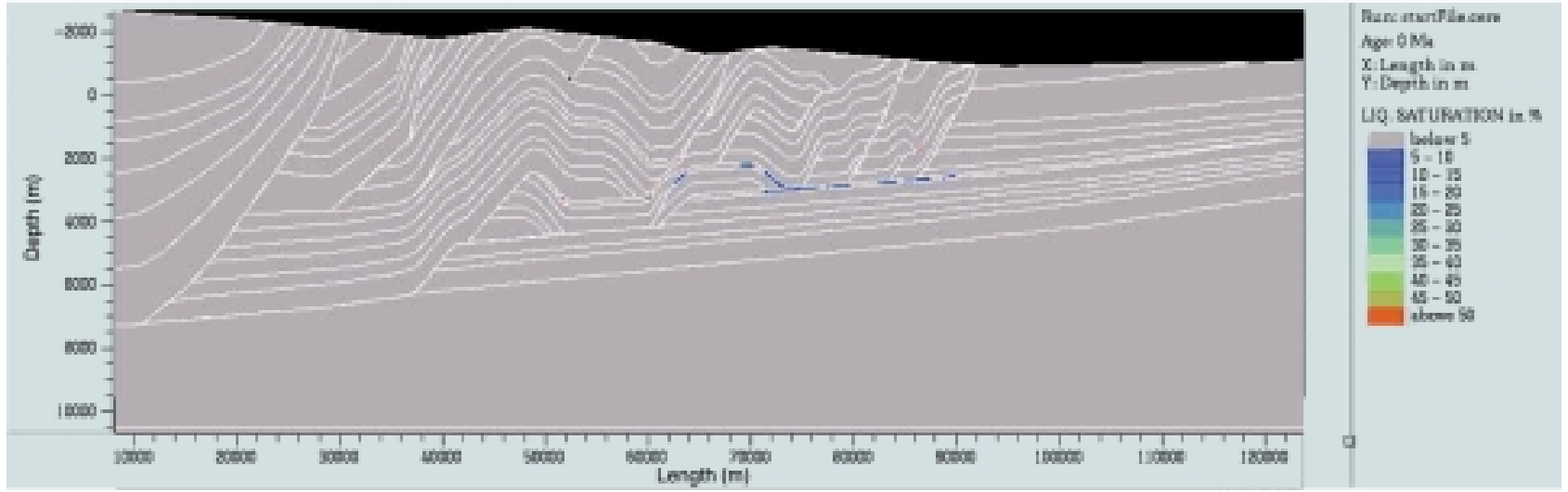

\section{Gas saturation}

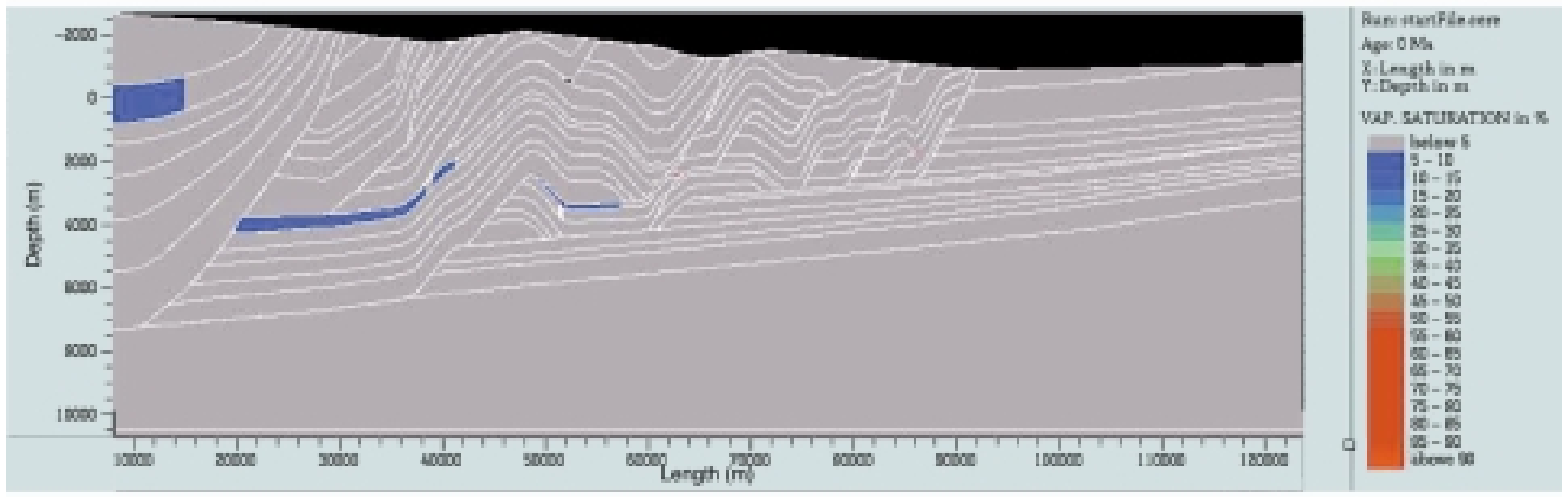

Figure 16b

Maturity evolution of all other Mesozoic and Cenozoic source rocks and coeval hydrocarbon charge of foothills reservoirs, as computed with Ceres. 


\section{Transformation ratio}

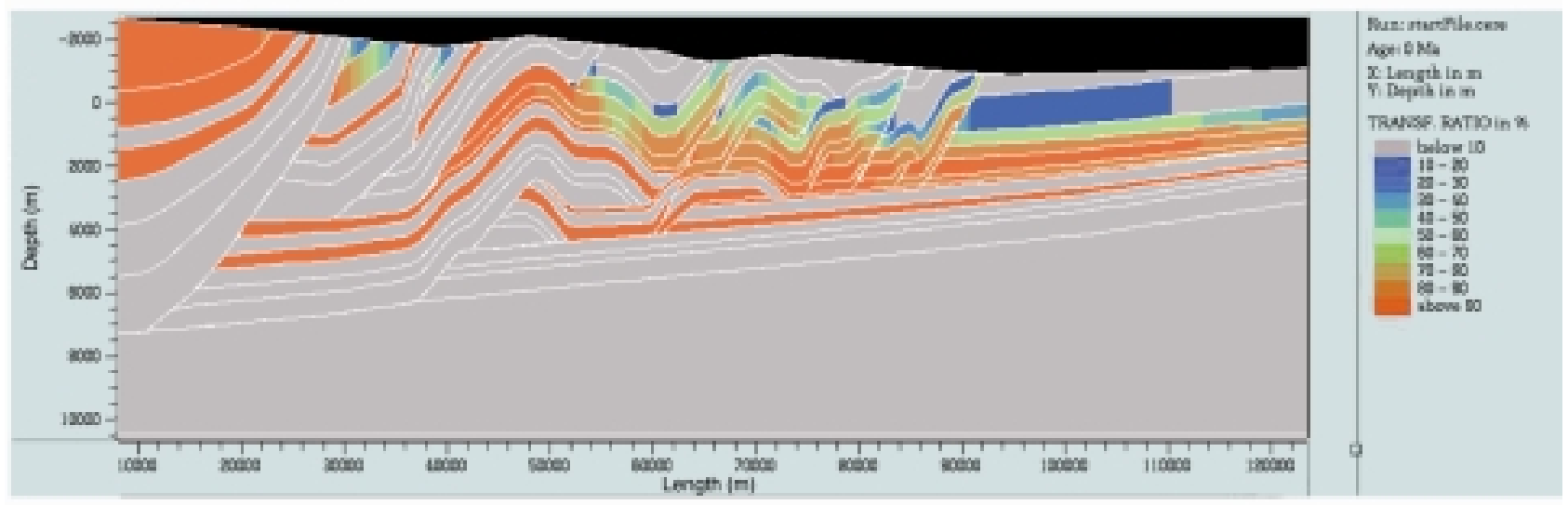

\section{Oil saturation}

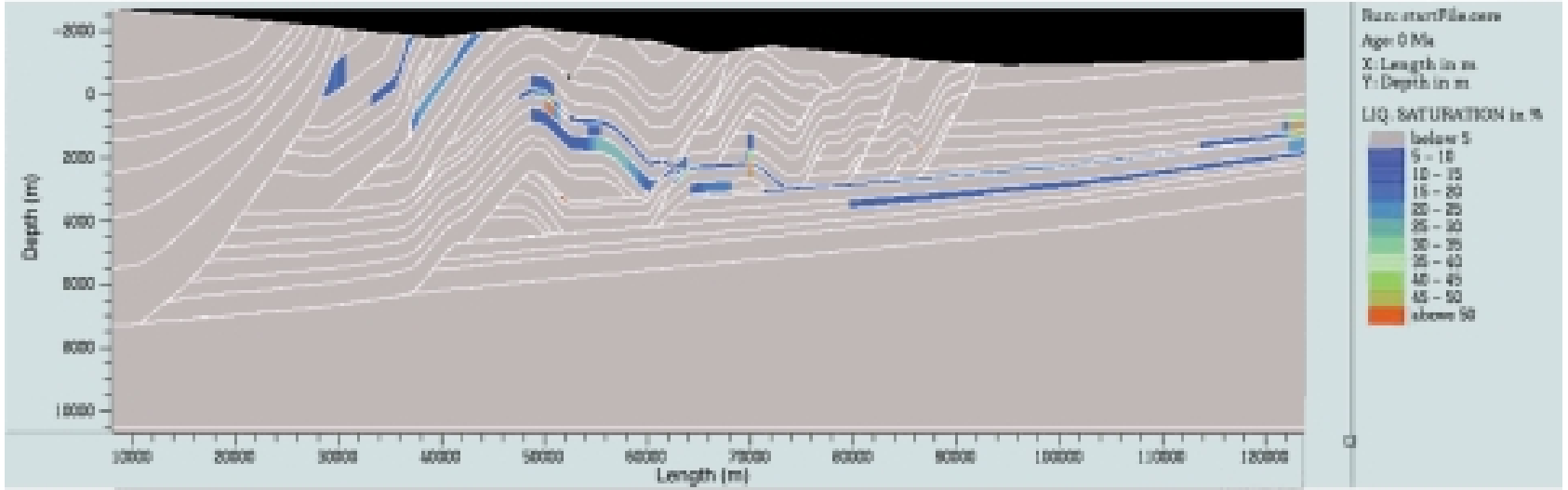

\section{Gas saturation}

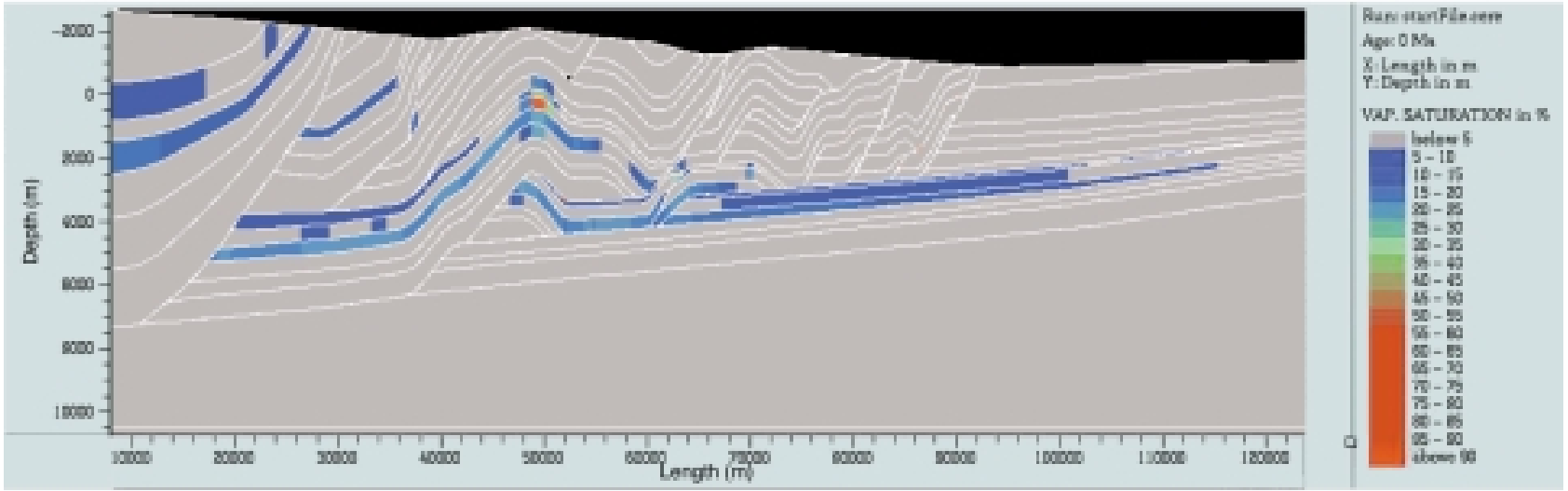

Figure 16c

Maturity evolution of all potential source rocks, including Exshaw and other organic rich formations, and total hydrocarbon charge of foothills reservoirs. Notice also the long lasting charge of foreland prospects, resulting from the diachronous maturation of source rock horizons across the section, both verticaly and lateraly. 
imposed here at 5\%. Paleozoic source rocks already reached a noticeable maturity (TR > 5\%) $80 \mathrm{Ma}$ ago, and became overmature $(\mathrm{TR}=100 \%)$ since $59 \mathrm{Ma}$.

When referring to the oil versus gas ratios, it is worth mentioning that source rocks actually generated only oil. Gas was produced later by secondary cracking. Results clearly show that secondary cracking mainly controls the present day oil versus gas distribution along the regional transect. For instance, oil is never present below $4.5 \mathrm{~km}$ of present-day burial. Below this depth, only gas accumulations occur. This could explain the Turner Valley oil accumulation in the Moose Mountain oil field at the less than $4.5 \mathrm{~km}$ depth.

In currently shallower subthrust structures, hydrocarbon charge began between 65 and $63 \mathrm{Ma}$. Although they are less buried today, these shallow structures originated farther to the west, in areas which were initially buried deeper beneath the synflexural sequence, and which became tectonically accreted into the allochthon at an earlier stage than adjacent, currently deeper, more external duplexes. Due to their inner position, these shallow prospects record an early oil charge history, which was followed by a second episode of gas filling from $55 \mathrm{Ma}$ to present, the early entrapped oil being progressively pushed down and replaced by gas. In this case again, late gas was certainly produced by secondary cracking in deeper parts of the section.

\section{CONCLUSIONS}

The unique data base of the Alberta foothills and adjacent foreland provided enough constraints to reconstruct consistent scenarios for the kinematic and thermal evolution of this classic foreland fold-and-thrust belt, which is also a world-class petroleum province. This case study provided also an opportunity to validate the use of $1 \mathrm{D}$ and $2 \mathrm{D}$ numerical tools developed at IFP for the prediction of hydrocarbon maturation, migration and charge in a tectonically complex area.

Early exploratory success in the Canadian Cordilleran petroleum province resulted from the application of the anticlinal paradigm in a region where the combination of sedimentation and diagenesis provided large sheet-like petroleum reservoirs and regional top-seals that were continuously developed across the structures, particularly in the Carboniferous ramp-carbonates. This allowed the straightforward empirical, albeit challenging, exploration for prospects where reservoirs were typically found to have been charged if structures could be identified and drilled, even where part of the seal is commonly provided by the underlying thrust fault. The development of these primary prospects identified, through the course of additional drilling, other stratigraphic levels that also contained productive reservoirs. Within these secondary shallower and deeper reservoirs the petroleum resources and reservoir quality could not be so simply and reliably associated with structural culminations. The identification, analysis and evaluation of these secondary potential reservoirs will be the basis for future discoveries and reserves addition in the Canadian Cordillera. Syntheses and analyses like the Subtrap provide important tools for both the elucidation of processes and mechanisms that control porosity and permeability within the well developed, major producing reservoirs, enriching and improving the empirical models of petroleum occurrence and exploration that are well established. In addition such syntheses and analyses provide a method for the prediction of process and mechanisms that enhanced or degraded reservoir quality and prospectivity in the next generation of foothills prospects to be exploited. The process of making such models forces a synthesis of existing, but diverse data sources. This synthesis, in turn provides a framework from which the important syntectonic kinematic and diagenetic processes can be inferred and analyzed for the benefit of future exploration and development.

The integrated methodology proposed here, coupling 1D (Genex-Gentec) and 2D Thrustpack simulations to constrain the overall kinematic and thermal evolution of the foothills, provides key boundary conditions for more sophisticated basin modeling tools such as the one performed with Ceres. Intermediate geometries constructed by means of forward simulations can be used as subsequent targets geometries when performing the backstripping and fluid flow-migration modeling with Ceres.

Further implementation of reservoir appraisal in such complex areas would require even more coupling, for instance between kinematic (Thrustpack software) and sedimentological (Dionisos software, Granjeon and Joseph, 1999) tools, in order to better define the sandstone versus shale ratio of synorogenic deposits, and to predict lateral shaling out and interfigering of seals and porous conduits, which are likely to control the detailed distribution of overpressure, hydraulic fracturing and seal damaging during subsequent Ceres fluid flow and pore fluid pressure simulations. First attempts of such tectonic-sedimentation modeling have already been performed in the Apennines (Albouy et al., 2003a and b), providing the hope for further improvement of such simulations in any thrust belt in the future.

Tectonic (layer parallel shortening-LPS) and chemical compactions (diagenesis) are two other parameters that should be taken into account by future basin modeling tools, in addition to burial and tectonic loading, when computing the pore fluid pressure history. Current tools, the one used in this study, are mainly 1D and 2D. Ultimately, break-through developments are also expected in the future to allow truly quantitative petroleum appraisal of foothills areas, by means of 3D numerical approaches.

The results of this study illustrate that there is an intimate and critical linkage between deformation, reservoir diagenesis and petroleum system function. The paragenetic 
scheme indicates that dolopackstones and dolowackstones with limestone skeletal fragments best survive the general degradation of reservoir quality that occurs during burial in the autochthonous footwall setting, as the petroleum source rocks reach their peak maturity and secondary migration begins. As the footwall is incorporated in the allochthon, it is deformed to provide a trap for the migrating petroleum, contemporaneous with the dissolution of calcite and limestone that results in the moldic porosity which is the primary reservoir texture. Thus the trap and reservoir are inferred to be formed dynamically in close temporal relationship with generation of the petroleum. As a result the risks of petroleum occurrence in foreland thrust and fold belts is seen to depend critically on the timing of the deformation as a function of the reservoir lithology. The elucidation of these critical relationships between petroleum systems and kinematics provides the first indications for a dynamic model of Foreland thrust and fold belt petroleum provinces, both locally and globally.

\section{ACKNOWLEDGEMENTS}

This study was performed in the scope of the Subtrap-II consortium, which was conducted by IFP in 1999-2001, being sponsored by Conoco, Enterprise, GDF, IntevepPDVSA, Lasmo and Total. We would like to acknowledge also James Buchanan, Lori Summa and Dick Nieuwland, which convinced us to move to Alberta for further developments of our research project, after phase I of the Subtrap Consortium.

This Canadian transect benefited from the direct assistance and participation of the Geological Survey of Canada. Our understanding of the regional geology greatly benefited from field trips and discussions with Glen Stockmal, Peter Fermor and Ray Price. Philippe Robion (University of Cergy) and Rudy Swennen (University of Leuven) participated in the field campaigns and provided additional informations on reservoirs deformation and diagenesis. William Sassi and Jean-Luc Rudkiewicz provided assistance when operating the Thrustpack package. The Banff and Kootenay national parks provided also authorization for sampling paleothermometers in key outcrops along the transect.

We also benefited from fruitfull discussions with Michael McGroder and Hans Machel in June 2002 during an AAPGHedberg conference held in Sicily on deformation, fluid flow and reservoir appraisal.

\section{REFERENCES}

Albouy, E., Casero, P., Eschard, R., Barrier, B. and Rudkiewicz, J.L. (2003) Coupled Structural/Stratigraphic Forward Modeling in the Central Apennines. AAPG Annual Convention, May 11-14, 2003, Salt Lake City, Utah.
Albouy, E., Casero, P., Eschard, R., Rudkiewicz, J.L. and Barrier, L. (2003) Structural/Stratigraphic Modelling of the Wedge Top Basin in the Central Apennines. AAPG International Conference and Exhibition, Barcelone, Espagne.

Ardic, C. (1998) Quantitative Basin Modeling, Hydrocarbon Generation and Migration History of the Moose Mountain Area, Rocky Mountain Foothills, Alberta. PhD Thesis, Univ. Calgary.

Bally, A.W., Gordy, P.L. and Stewart, G.A. (1966) Structure, Seismic Data, and Orogenic Evolution of Southern Canadian Rocky Mountains. Bulletin of Canadian Petroleum Geology, 14, 337-381.

Bachu, S. (1999) Flow Systems in the Alberta Basin: Patterns, Types and Driving Mechanisms. Bulletin of Canadian Petroleum Geology, 47, 4, December 1999, 455-474.

Bachu, S. (1993) Basement Heat Flow in the Western Canada Sedimentary Basin. Tectonophysics, 222, 119-133.

Bachu, S. and Burwash, R.A. (1991) Regional Scale Analysis of the Geothermal Regime in the Western Canada Sedimentary Basin. Geothermics, 20, 387-407.

Bally, A.W., Gordy P.L. and Stewart G.A. (1966) Structure, Seismic Data, and Orogenic Evolution of Southern Canadian Rocky Mountains. Bulletin of Canadian Petroleum Geology, 14, 337-381.

Beaumont, C. (1981) Foreland Basins. Geophysical Journal of the Royal Astronomical Society, 65, 291-329.

Benaouali, Z.N., Faure, J.L., Bracene, B., Roure, F., Frizon De Lamotte, D. and Osadetz, K. (2003) Thrust Kinematics, Uplift and Erosion in Foreland Fold-and-Thrust Belts: Comparative Study of Canadian Rockies and the Saharan Atlas-North Algeria. AAPG Annual Convention, May 11-14, 2003, Salt Lake City, Utah.

Burgess, P., Gurnis, M., and Moresi, L. (1997) Formation of Sequences in the Cratonic Interior of North America by Interaction between Mantle, Eustatic, and Stratigraphic Process. Geological Society of America Bulletin, 108, 1515-1535.

Carr, S. (1992) Tectonic Setting and U-Pb Geochronology of the Early Tertiary Ladybird Leucogranite Suite, Thor-OdinPinnacles Area, Southern Omineca Belt, British Columbia: Tectonics, 11, 258-278.

Carr, S.D., Parrish, R.R. and Brown, R.L. (1987) Eocene Structural Development of the Valhalla Complex, Southeastern British Columbia. Tectonics, 6, 175-196.

Covey, M.C., Vrolijk, P.J., Pevear, D.R. and Lariviere, A.J. (1994) Direct Dating of Fault Movement in the Rocky Mountain Front Ranges of Southern Alberta. Annual GSA mtg, Seattle, 10/24-27/94, 26, 7, 467.

Dahlen, FA and Suppe, J. (1984) Mechanics of Fold and Thrust Belts and Accretionary Wedges: Cohesive Coulomb Theory. Jour. Geophys. Res., 89, 10087-10101.

Dahlstrom, C.D.A. (1970) Structural Geology in the Eastern Margin of the Canadian Rocky Mountains. Bulletin of Canadian Petroleum Geology, 18, 332-406.

Davis, D.A., Suppe, J. and Dahlen, F.A. (1983) Mechanics of Fold and Thrust Belts and Accretionary Wedges. Jour. Geophys. Res., 88, 1153-1172.

Douglas, R.J.W. (1950) Callum Creek, Langford Creek and Gap Map-Areas. Geological Survey of Canada, Memoir 255.

Doughty, P.T. and Price, R.A. (1999) Tectonic Evolution of the Priest River Complex, Northern Idaho and Washington: A Reappraisal of the Newport Fault with New Insights on Metamorphic Core Complex Formation. Tectonics, 18, 375-393.

Doughty, P.T. and Price, R.A. (2000) Geology of the Purcell Trench Rift Valley and Sandpoint Conglomerate: Eocene "en échelon" normal Faulting and Synrift Sedimentation along the 
Eastern Flank of the Priest River Metamorphic Complex, Northern Idaho. Geological Society of America Bulletin, 112, 1356-1374.

England, T.D.J. and Bustin, R.M. (1986) Thermal Maturation of the Western Canadian Sedimentary Basin south of the Red Deer River: I - Alberta Plains. Bulletin of Canadian Petroleum Geology, 34, 71-90.

Espitalié, J., Deroo, G. and Marquis, F. (1985) La pyrolyse RockEval et ses applications. Revue de l'Institut français du pétrole, 40, 563-579 and 755-784.

Ewing, T.E. (1980) Paleogene Tectonic Evolution of the Pacific Northwest. Journal of Geology, 88, 619-638.

Faure, J.L., Ait Brahim, S., Benaouali, N., Gaumet, F., Osadetz, K., Schmidt, J., Schneider, F., Swennen, R., Robion, P. and SUBTRAP Team, (2002a) SUBTRAP Alberta Transect. In final report of the SUBTRAP-II Consortium, IFP Report no. 56470, Chapter III.

Faure, J.L., Benaouali, N., Osadetz, K. and Roure, F. (2002b) Tectonic and Thermal Forward Modelling of Canadian Foothills. An Essential Approach for Reservoir Appraisal, Fluid Flow and Pore Pressure History. Extend Abstract, AAPG Hedberg Conference: Deformation History, Fluid Flow Reconstruction and Reservoir Appraisal in Foreland Fold and Thrust Belts, May 1418, 2002, Palermo-Mondello, Sicily, Italy.

Schneider, F., Faure, J.L. and Roure, F. (2002) Methodology for Basin Modeling in Complex Area: Examples from Eastern Venezuelan and Canadian Foothills. Extend Abstract, AAPG Hedberg Conference: Deformation History, Fluid Flow Reconstruction and Reservoir Appraisal in Foreland Fold and Thrust Belts, May 14-18, 2002, Palermo-Mondello, Sicily, Italy.

Fermor, P. (1999) Aspects of the Three-Dimensional Structure of the Alberta Foothills and Front Ranges. Geological Society of America Bulletin, 111, 3, 317-346.

Fermor, P.R. and Moffat, I.W. (1992) Tectonics and Structure of the Western Canada Foreland Basin; R.W. Macqueen and D.A. Leckie Foreland Basins and Fold Belts American Association of Petroleum Geologists, Memoir 55, 81-105.

Fermor, P.R. and Price, R.A. (1987) Multiduplex Structure along the Base of the Lewis Thrust Sheet in the Southern Canadian Rockies. Bulletin of Canadian Petroleum Geology, 35, 159-185.

Forbes, P., Ungerer, P., Kuffus, A., Riis, F. and Enggen, S. (1991) Compositional Modeling of Petroleum Generation and Expulsion. AAPG Bulletin, 75, 873-893

Gabrielse, H. and Yorath, C.J. (1992) Geology of the Cordilleran Orogen in Canada. Geological Survey of Canada, Geology of Canada, 4.

Granjeon, D. and Joseph, P. (1999) Concepts and Applications of a 3D Multiple Lithology, Diffusive Model in Stratigraphc Modeling. In: Harbough, J.W. et al. (eds), Numerical Experiments in Stratigraphy, SEPM, Sp. Publ., 62.

Hacquebard, P.A. (1977) Rank of Coal as an Index of Organic Metamorphism for Oil and Gas in Alberta, Deroo, G., Powell, T.G., Tissot, B. and McCrossan, R.G. eds., The Origin and Migration of Petroleum in the Western Canadian Sedimentary Basin, Alberta - A Geochemical and Thermal Maturation Study. Geological Survey of Canada, Bulletin, 262, 11-22.

Hacquebard, P.A. and Donaldson, J.R. (1974) Rank Studies of Coals in the Rocky Mountains and Inner Foothills Belt, Canada. In: Dutcher, R.R., Hacquebard, P.A., Schopf, J.M. and Simon, J.A. eds., Carbonaceous Materials As Indicators of Metamorphism. Geological Society of America, Special Paper 153, 75-94.

Hughes, J.D. and Cameron, A.R. (1985) Lithology, Depositional Setting and Coal Rank-Depth Relationships in the JurassicCretaceous. Kootenay Group at Mount Allan, Cascade Coal Basin, Alberta. Geological Survey of Canada, Paper 81-11.
Hoy, T. and Van der Heyden, P. (1988) Geochemistry, Geochronology, and Tectonic Implications of Two Quartz Monzonite Intrusions, Purcell Mountains, Southeastern Brithish Columbia. Canadian Journal of Earth Sciences, 25, 106-115.

Issler, D.R., Beaumont, C., Willett, S.D., Donelick, R.A., Mooers, J. and Grist, A. (1990) Preliminary Evidence from Apatite FissionTrack Data Concerning the Thermal History of the Peace River Arch region, Western Canada Sedimentary Basin. Bulletin of Canadian Petroleum Geology, 38A, 250-269.

Jerzykiewicz, T., Sweet, A.R. and McNeil, D.H. (1996) Shoreface of the Bearpaw Sea in the Footwall of the Lewis Thrust, Southern Canadian Cordillera, Alberta. In: Current Research 1996-A, Geological Survey of Canada, 15-163.

Lorencak, M., Seward, D., Vanderhaeghe, O., Teyssier, C. and Burg, J.P. (2001) Low-Temperature Cooling History of the Shuswap Metamorphic Core Complex, British Columbia: constraints from Apatite and Zircon Fission-Track Ages. Canadian Journal of Earth Sciences, 38, 11, 1615-1625.

Machel, H.G. and Cavell, P.A. (1999) Low-Flux, Tectonically Induced Squeegee Fluid Flow ("Hot Flash") into the Rocky Mountain Foreland Basin. Bull. Can. Petrol. Geol., 47, 4, 510533.

Mack, G.H. and Jerzykiewicz, T. (1989) Provenance of PostWapiabi Sandstones and its Implications for Campanian to Palaeocene Tectonic History of the Southern Canadian Cordillera. Canadian Journal of Earth Sciences, 26, 665-676.

Magara, K. (1976) Thickness of Removed Sedimentary Rocks, Paleopore Pressure and Paleotemperature, Southwestern Part of Western Canada Basin. American Association of Petroleum Geologists, Bulletin, 60, 554-565.

Majorowicz, J.A. and Jessop, A.M. (1993) Relation between Basement Heat Flow and Thermal State of the Sedimentary Succession of the Alberta Plains. Bulletin of Canadian Petroleum Geology, 41, 358-368.

Majorowicz, J.A., Garven, G., Jessop, A. and Jessop, C. (1999) Present Heat Flow Profile Across the Western Canada Sedimentary Basin: the Extent of Hydrodynamic Influence. In: Forster, A. and Marriam, D.F., eds., Geothermics in Basin Analysis, Plenum Publishing Corporation, 61-79.

Majorowicz, J.A., Jones, F.W., Ertman, M.E., Osadetz, K.G. and Stasiuk, L.D. (1990) The Relationship between Thermal Maturation Gradients, Geothermal Gradients and Estimates of the Thickness of the Eroded Foreland Section, Southern Alberta Plains, Canada. Marine and Petroleum Geology, 7, 138-152.

Monger, J.W.H. and Price, R.A. (1979) Geodynamic Evolution of the Canadian Cordillera-Progress and Problems. Canadian Journal of Earth Sciences, 16, 771-791.

Morretti, I. and Larrere M. (1989) Computer-Aided Construction of Balanced Geological Cross-Sections. Geobyte, 16-24.

Nurkowski, J.R. (1984) Coal Quality, Coal Rank Variation and its Relation to Reconstructed Overburden, Upper Cretaceous and Tertiary Plains coals, Alberta, Canada. American Association of Petroleum Geologists, Bulletin, 68, 285-295.

Osadetz, K.G., Kohn, B.P., Feinstein, S.S. and Price, R.A. (2000) Aspects of Foreland Belt Thermal and Geological History in the Southern Canadian Cordillera from Fission-Track Data. Extended Abstract, GeoCanada 2000.

Osadetz, K.G., Kohn, B., Feinstein, S. and Price, R. (2004) Foreland Belt Thermal History Using Apatite Fission Track Thermochronology: Implications for Lewis Thrust and Flathead Fault in the Southern Canadian Cordilleran Petroleum Province. In: Swennen, R., Roure, F. and Granath, J., eds., Fluid Flow, Deformation History and Reservoir Appraisal in Foreland Foldand-Thrust Belts. AAPG Mem., in press.

Parrish, R.R., Carr, S.D. and Parkinson, D.L. (1988) Eocene Extensional Tectonics and Geochronology of the Southern 
Omineca Belt, British Columbia and Washington. Tectonics, 7, 181-212.

Peper, T. (1993) Tectonic Control on the Sedimentary Record in Foreland Basins: Inferences from Quantitative Subsidence Analyses and Stratigraphic Modeling. Thesis and supplement, Vrije Universiteit Amsterdam, CIP-DATA Doninklijke Bibliotheek, Den Haag.

Poulton, T.P., Christopher, J.E., Hayes, B.J.R., Losert, J. Tittemore, J. and Gilchrist, R.D. (1994) Jurassic and Lowermost Cretaceous Strata of the Western Canada Sedimentary Basin. In: Mossop, G.D. and Shetsen, I., eds., Geological Atlas of the Western Canada Sedimentary Basin, CSPG and Alberta Research Council, 297-316.

Price, R.A. (2000) The Evolution of the Southern Cordiellan Foreland Thrust and Fold Belt and the Kinematics of Cordieran Orogenesis. Extend Abstract, GEOCANADA 2000.

Price, R.A. (1994) Chapter 2: Cordilleran Tectonics and the Evolution of the Western Canada Sedimentary Basin. In: Mossop, G. and Shetsen, I. (compilers), Geological Atlas of the Western Canada Sedimentary Basin. Canadian Society of Petroleum Geologists and Alberta Research Council, Calgary and Edmonton, 13-24.

Price, R.A. (1981) The Cordilleran Thrust and Fold Belt in the Southern Canadian Rocky Mountains. In: Thrust and Nappe tectonics, McClay, K.R. and Price, N.J. (eds.), Geological Society of London, Special Publication, 9, 427-448.

Price, R.A. (1973) Large-Scale Gravitational Flow of Supracrustal Rocks, Southern Canadian Rockies. In: Gravity and Tectonics. De Jong, K.A. and Scholten, R. (eds.), New York, Wiley and Sons, 491-502.

Price, R.A. and Fermor, P.R. (1985) Structure Section of the Cordilleran Foreland Thrust and Fold Belt West of Calgary, Alberta. Geological Survey of Canada, Paper, 84-14.

Price, R.A. and Fermor, P.R. (1982) Structure Section of the Cordilleran Foreland Thrust and Fold Belt West of Calgary, Alberta. Geol. Survey of Canada, Open File Report 882.

Robion, Ph., Faure, J.L. and Swennen, R. (2004) Late Cretaceous Chemical Remagnetization of the Paleozoic Carbonates from the Undeformed Foreland of the Western Canadian Cordillera. In: Fluid Flow, Deformation History and Reservoir Appraisal in Foreland Fold-and-Thrust Belts, Swennen, R., Roure, F. and Granath, J. eds., $A A P G$ Mem., in press.

Roure, F., Faure, J.L., Gaumet, F., Sassi, W., Schmidt, J., Ait Brahim, S., Bard, J.F., Benaouali, N., Benchilla, L., Marquis, F., Schmitt, M., Osadetz, K., Hernandez, E., Akhtar, K., Jaswal, T., Khan, S.A., Malik, J., Pagel, M., Pichon, O., Dufaure, O., Robion, P. and Swennen, R. (2002) Final Report of the SUBTRAP-II Consortium. IFP Report no. 56470.

Roure, F. and Sassi, W. (1995) Kinematic of Deformation and Petroleum System Appraisal in Neogene Foreland-Fold-and Thrust Belts. Petroleum Geosciences, 1, 253-269.

Roure, F. and Swennen, R., convenors (2002) Deformation, Fluid Flow and Reservoir Appraisal in Foreland Fold and Thrust Belts. AAPG-IFP Hedberg Conference, Abstract volume, 14-18 May 2002, Palermo, Sicily.
Roure, F., Swennen, R. and Howell, D.G. (2000) Subthrust Reservoir Appraisal. World Petroleum Conference, Proceedings, Calgary, Alberta, Canada.

Sassi, W. and Rudkiewicz, J.L. (1999) THRUSTPACK Version 6.2: 2 D Integrated Maturity Studies in Thrust Areas. IFP Report no. 45372 .

Sassi, W. and Rudkiewicz, J.L. (2000) Computer Modelling of Petroleum Systems along Regional Cross-Sections in Foreland and Fold-and-Thrust Belts. EAGE Conference, Malta 2000, Extended Abstract.

Schneider, F. (2003) Basin Modeling in Complex Area: Examples from Eastern Venezuelan and Canadian foothills. Oil \& Gas Science and Technology, Revue de l'IFP, 58, 2, 313-324.

Schneider, F., Devoitine, H., Faille, I., Flauraud, E. and Willien, F. (2002) Ceres 2D: A Numerical Prototype for HC Potential Evaluation in Complex Area. Oil \& Gas Science and Technology, Revue de l'IFP, 54, 6, 607-619.

Snowdon, L.R. (1997) Rock-Eval/TOC Data for Six Alberta Foothills Wells (Townships 23 to 27 and Ranges 5W5 to 7W5). Geological Survey of Canada, Open File 3493.

Stockmal, G.S., Osadetz, K.G., Lebel, D. and Hannigan, P.K. (2001) Structure and Hydrocarbon Occurrence, Rocky Mountain Foothills and Front Ranges, Turner Valley to Waterton Lake Fieldtrip Guidebook. Geological Survey of Canada, Open File 4111 .

Swennen, R., Faure, J.L., Osadetz, K., Robion, P. and Roure, F. (2002) Mesodolomite Formation As A Result of Layer Parallel Shortening and Secondary Porosity Development by Cooling of Formation Waters or Cooling Due to Thrust Emplacement: An Example from the Canadian Foreland Fold and Thrust Belt. Extend Abstract, AAPG Hedberg Conference: Deformation History, Fluid Flow Reconstruction and Reservoir Appraisal in Foreland Fold and Thrust Belts, May 14-18, 2002, PalermoMondello, Sicily, Italy.

Swennen, R., Ferket, H., Benchilla, L., Roure, F., Muska, K., Ellam, R. and Subtrap team (2002) Diagenesis In Foreland Fold and Thrust Belts: Synthesis of an Overregional Study. Extend Abstract, AAPG Hedberg Conference: Deformation History, Fluid Flow Reconstruction and Reservoir Appraisal in Foreland Fold and Thrust Belts, May 14-18, 2002, Palermo-Mondello, Sicily, Italy.

Vanderhaeghe, O., Tessier, C., McDougall, I. and Dunlap, W.J. (2003) Cooling and Exhumation of the Shuswap Metamorphic Core Complex constrained by 40Ar/39Ar Thermochronology. Geological Society of America Bulletin, 115, 200-216.

Widdowson, R.G. (1993) Structural Cross Section through Moose Mountain. In: Mundy, D.J.C. and Widdowson, R.G. eds (1993) Stratigraphy, Sedimentology, Structural Geology and Exploration History of the Mississippian at Moose Mountain, Southwesten Alberta Footbills. Field Trip Guide for 1993 CSPG Annual Convention.

Final manuscript received in December 2003 or distributed for profit or commercial advantage and that copies bear this notice and the full citation on the first page. Copyrights for components of this work owned by others than IFP must be honored. Abstracting with credit is permitted. To copy otherwise, to republish, to post on servers, or to redistribute to lists, requires prior specific permission and/or a fee. Request permission from Documentation, Institut français du pétrole, fax. +33147527078 , or revueogst@ifp.fr. 